\title{
Reviews and syntheses: Four decades of modeling methane cycling in terrestrial ecosystems
}

\author{
Xiaofeng Xu ${ }^{1,2,3}$, Fengming Yuan ${ }^{4}$, Paul J. Hanson ${ }^{4}$, Stan D. Wullschleger ${ }^{4}$, Peter E. Thornton ${ }^{4}$, William J. Riley ${ }^{5}$, \\ Xia Song ${ }^{1,3}$, David E. Graham ${ }^{6}$, Changchun Song ${ }^{2}$, and Hanqin Tian ${ }^{7}$ \\ ${ }^{1}$ Biology Department, San Diego State University, San Diego, CA, USA \\ ${ }^{2}$ Northeast Institute of Geography and Agro-ecology, Chinese Academy of Sciences, Changchun, Jilin, China \\ ${ }^{3}$ Department of Biological Sciences, University of Texas at El Paso, El Paso, TX, USA \\ ${ }^{4}$ Climate Change Science Institute and Environmental Sciences Division, \\ Oak Ridge National Laboratory, Oak Ridge, TN, USA \\ ${ }^{5}$ Earth Sciences Division, Lawrence Berkeley National Laboratory, Berkeley, CA, USA \\ ${ }^{6}$ Biosciences Division, Oak Ridge National Laboratory, Oak Ridge, TN, USA \\ ${ }^{7}$ International Center for Climate and Global Change Research, School of Forestry and Wildlife Sciences, \\ Auburn University, Auburn, AL, USA
}

Correspondence to: Xiaofeng Xu (xxu@mail.sdsu.edu)

Received: 3 February 2016 - Published in Biogeosciences Discuss.: 12 February 2016

Revised: 1 June 2016 - Accepted: 2 June 2016 - Published: 28 June 2016

\begin{abstract}
Over the past 4 decades, a number of numerical models have been developed to quantify the magnitude, investigate the spatial and temporal variations, and understand the underlying mechanisms and environmental controls of methane $\left(\mathrm{CH}_{4}\right)$ fluxes within terrestrial ecosystems. These $\mathrm{CH}_{4}$ models are also used for integrating multi-scale $\mathrm{CH}_{4}$ data, such as laboratory-based incubation and molecular analysis, field observational experiments, remote sensing, and aircraft-based measurements across a variety of terrestrial ecosystems. Here we summarize 40 terrestrial $\mathrm{CH}_{4}$ models to characterize their strengths and weaknesses and to suggest a roadmap for future model improvement and application. Our key findings are that (1) the focus of $\mathrm{CH}_{4}$ models has shifted from theoretical to site- and regional-level applications over the past 4 decades, (2) large discrepancies exist among models in terms of representing $\mathrm{CH}_{4}$ processes and their environmental controls, and (3) significant datamodel and model-model mismatches are partially attributed to different representations of landscape characterization and inundation dynamics. Three areas for future improvements and applications of terrestrial $\mathrm{CH}_{4}$ models are that (1) $\mathrm{CH}_{4}$ models should more explicitly represent the mechanisms underlying land-atmosphere $\mathrm{CH}_{4}$ exchange, with an emphasis on improving and validating individual $\mathrm{CH}_{4}$ processes over
\end{abstract}

depth and horizontal space, (2) models should be developed that are capable of simulating $\mathrm{CH}_{4}$ emissions across highly heterogeneous spatial and temporal scales, particularly hot moments and hotspots, and (3) efforts should be invested to develop model benchmarking frameworks that can easily be used for model improvement, evaluation, and integration with data from molecular to global scales. These improvements in $\mathrm{CH}_{4}$ models would be beneficial for the Earth system models and further simulation of climate-carbon cycle feedbacks.

\section{Introduction}

Methane $\left(\mathrm{CH}_{4}\right)$ is the second-most important anthropogenic greenhouse gas, accounting for $\sim 15 \%$ of anthropogenic forcing to climate change (Forster et al., 2007; IPCC, 2013; Rodhe, 1990). Therefore, an accurate estimate of $\mathrm{CH}_{4}$ exchange between land and the atmosphere is fundamental for understanding climate change (Bridgham et al., 2013; Nazaries et al., 2013; Spahni et al., 2011). The ecosystem modeling approach has been one of the most broadly used integrative tools for examining mechanistic processes, quantifying the budget of $\mathrm{CH}_{4}$ flux across spatial and temporal 
scales (Arah and Stephen, 1998; Riley et al., 2011; Walter et al., 1996; Zhuang et al., 2004) and predicting future flux (Anisimov, 2007). Specifically, many $\mathrm{CH}_{4}$ models have been developed to integrate data, improve process understanding, quantify budgets, and project exchange with the atmosphere under a changing climate (Cao et al., 1995; Grant, 1998; Huang et al., 1998a; Potter, 1997). In addition, model sensitivity analyses help to design field and laboratory experiments by identifying the most uncertain processes and parameters in the models (Massman et al., 1997; Xu, 2010).

Based on the complexity of the $\mathrm{CH}_{4}$ processes represented, $\mathrm{CH}_{4}$ models fall into two broad categories: (1) empirical models that are used to estimate and extrapolate measured methanogenesis, methanotrophy, or $\mathrm{CH}_{4}$ emission at plot, country, or continental scales (Christensen et al., 1996; Eliseev et al., 2008; Mokhov et al., 2007; Wania et al., 2009, 2010); and (2) process-based models that are used for prognostic understanding of individual $\mathrm{CH}_{4}$ processes in response to multiple environmental drivers and budget quantification (reviewed below). This separation emphasizes the high-level model structure rather than the specific processes represented; therefore, models with many processes represented with empirical functions are still classified as processbased models if they represent many key processes of $\mathrm{CH}_{4}$ production, oxidation, and transport. Although this separation is rather arbitrary, it helps one to understand the characteristics and purpose of models in a systems perspective.

Over the past decades, many empirical and process-based models have been developed, for example, CASA (Potter, 1997), CH4MOD (Huang et al., 1998b), CLM4Me (Riley et al., 2011), DAYCENT (Del Grosso et al., 2000), DLEM (Tian et al., 2010; Xu and Tian, 2012), DNDC (Li, 2000), ecosys (Grant, 1998), HH (Cresto Aleina et al., 2015), MEM (Cao et al., 1995), and TEM (Zhuang et al., 2004). However, recent analyses and model inter-comparisons have shown that most of these models poorly reproduce regionalto global-scale observations (Bohn and Lettenmaier, 2010; Bohn et al., 2015; Melton et al., 2013; Wania et al., 2013). A comprehensive synthesis and evaluation of the mechanisms incorporated into these models is lacking. This review focuses on primary processes of $\mathrm{CH}_{4}$ cycling in the terrestrial ecosystems and their representation in the models. The critical $\mathrm{CH}_{4}$ processes include substrate cycling, methanogenesis, methanotrophy, and transport in the soil profile, and their environmental controls. Emphasis is given to how these mechanisms were simulated in various models and how they were categorized in terms of complexity and ecosystem function. The review focuses on $\mathrm{CH}_{4}$ models developed for terrestrial ecosystems, which is defined as ecosystems on land and wetlands with less than $2 \mathrm{~m}$ standing water. This classification is used to distinguish them from pure aquatic ecosystems and considering the important role of wetlands in $\mathrm{CH}_{4}$ cycling. Therefore, models for understanding reactions in bioreactors (Bhadra et al., 1984; Pareek et al., 1999), mining plots (De Visscher and Van Cleemput, 2003), aquatic ecosys- tems, and marine systems (Elliott et al., 2011) were excluded. An early pioneering effort of multiplying wetland area by average $\mathrm{CH}_{4}$ flux to estimate global $\mathrm{CH}_{4}$ budget was excluded from this review as well (Matthews and Fungi, 1987). This review further excludes the $\mathrm{CH}_{4}$ emission from biomass burning, termites, and ruminants, because this paper primarily focuses on soil biogeochemical processes represented in ecosystem models. The model names are determined by two criteria: (1) if the model has been named in the original publication, it will be used to represent the model; (2) if the model has not been named, the last name of the first author will be used to name the model: for example, "Segers model" or "Gong model". In this paper we first provide an overview of the range of processes that have been considered in $\mathrm{CH}_{4}$ models over the past 4 decades, and then further classify existing models as determined by the range of processes considered. We finished with several suggested research topics, which would be beneficial for better developing and applying $\mathrm{CH}_{4}$ models for either understanding $\mathrm{CH}_{4}$ cycling or quantifying $\mathrm{CH}_{4}$ budgets at various scales.

\section{Primary $\mathrm{CH}_{4}$ processes}

Biological $\mathrm{CH}_{4}$ production in sediments was first noted in the late 18th century (Volta, 1777), and the microbial oxidation of $\mathrm{CH}_{4}$ was proposed at the beginning of the 20th century (Söhngen, 1906). Since then, $\mathrm{CH}_{4}$ cycling processes have been intensively studied and documented (Christensen et al., 1996; Hakemian and Rosenzweig, 2007; Lai, 2009; Melloh and Crill, 1996; Mer and Roger, 2001), and most have been described mathematically and incorporated into ecosystem models (Table 1). Herein, we do not attempt to review all $\mathrm{CH}_{4}$ processes, as a number of reviews have been published on this topic (Barlett and Harriss, 1993; Blodau, 2002; Bridgham et al., 2013; Cai, 2012; Chen et al., 2012; Conrad, 1995, 1996; Hakemian and Rosenzweig, 2007; Higgins et al., 1981; Lai, 2009; Monechi et al., 2007; Segers, 1998; Wahlen, 1993). Rather, we focus on primary $\mathrm{CH}_{4}$ processes in terrestrial ecosystems and their environmental controls from a modeling perspective. In this context there exist three major methanogenesis mechanisms, two $\mathrm{CH}_{4}$ methanotrophy mechanisms, and three aggregated $\mathrm{CH}_{4}$ transport pathways in plants and soils. We note that most models do not explicitly represent all of these transport pathways, and that the relative importance of these pathways varies substantially in time, space, and with ecosystem types. We also pay attention to several other modeling features, including capability for plot- or regional-level simulations, vertical representation of biogeochemical processes, and whether the model is embedded in an Earth system model (ESM).

The published literature concludes that two processes dominate biological $\mathrm{CH}_{4}$ production (Conrad, 1999; Krüger et al., 2001): acetoclastic methanogenesis $-\mathrm{CH}_{4}$ production from acetate - and hydrogenotrophic methanogenesis $-\mathrm{CH}_{4}$ 
Table 1. Terrestrial ecosystem models for $\mathrm{CH}_{4}$ cycling and the model representation of three pathways of $\mathrm{CH}_{4}$ transport (models are in alphabetical order; author's last name is used if the model name is not available).

\begin{tabular}{|c|c|c|c|c|}
\hline Model & Aerenchynma & Diffusion & Ebullition & References \\
\hline Beckett model & Yes & Yes & No & Beckett et al. (2001) \\
\hline Cartoon model & Yes & Yes & Yes & Arah and Stephen (1998); Arah and Kirk (2000) \\
\hline CASA & Yes & Yes & Yes & Potter (1997); Potter et al. (1996) \\
\hline CH4MOD & Yes & Yes & Yes & Huang et al. (1998b, 2004); Li et al. (2012) \\
\hline Christensen model & No & No & No & Christensen et al. (1996) \\
\hline CLASS & No & Yes & No & Curry $(2007,2009)$ \\
\hline CLM4Me & Yes & Yes & Yes & Riley et al. (2011) \\
\hline CLM-Microbe & Yes & Yes & Yes & Xu et al. $(2014,2015)$ \\
\hline DAYCENT & No & Yes & No & Del Grosso et al. $(2000,2002,2009)$ \\
\hline Ding model & Yes & No & No & Ding and Wang (1996) \\
\hline DLEM & Yes & Yes & Yes & Tian et al. (2010); Xu and Tian (2012) \\
\hline DNDC & Yes & Yes & Yes & $\mathrm{Li}(2000)$ \\
\hline DOS-TEM & Yes & Yes & Yes & Fan et al. (2013) \\
\hline ecosys & No & Yes & Yes & Grant $(1998,2001)$ \\
\hline Gong model & Yes & Yes & Yes & Gong et al. (2013) \\
\hline HH model & Yes & Yes & Yes & Cresto Aleina et al. (2015) \\
\hline IAP-RAS & No & No & No & Eliseev et al. (2008); Mokhov et al. (2007) \\
\hline Kettunen model & Yes & Yes & Yes & Kettunen (2003) \\
\hline Lovley model & No & No & No & Lovley and Klug (1986) \\
\hline LPJ-Bern & Yes & Yes & Yes & Spahni et al. (2011) \\
\hline LPJ-WHyMe & Yes & Yes & Yes & Wania et al. $(2009,2010)$ \\
\hline LPJ-WSL & No & No & No & Hodson et al. (2011) \\
\hline Martens model & Yes & Yes & Yes & Martens et al. (1998) \\
\hline MEM & No & No & No & Cao et al. $(1995,1998)$ \\
\hline MERES & Yes & Yes & No & Matthews et al. (2000) \\
\hline Nouchi model & Yes & Yes & No & Hosono and Nouchi (1997); Nouchi et al. (1994) \\
\hline ORCHIDEE & Yes & Yes & Yes & Ringeval et al. $(2010,2011)$ \\
\hline Ridgwell model & No & Yes & No & Ridgwell et al. (1999) \\
\hline SDGVM & No & No & No & Hopcroft et al. (2011) \\
\hline Segers model & Yes & Yes & Yes & Segers and Kengen (1998); Segers and Leffelaar (2001a, b); Segers et al. (2001) \\
\hline Tagesson model & No & No & No & Tagesson et al. (2013) \\
\hline TCF & Yes & Yes & Yes & Watts et al. (2014) \\
\hline TEM & Yes & Yes & Yes & Zhuang et al. (2004) \\
\hline TRIPLEX-GHG & Yes & Yes & Yes & Zhu et al. (2014) \\
\hline UW-VIC & Yes & Yes & Yes & Bohn and Lettenmaier (2010); Bohn et al. (2007) \\
\hline van Bodegom model & Yes & Yes & Yes & van Bodegom et al. $(2000,2001)$ \\
\hline VISIT & Yes & Yes & Yes & Inatomi et al. (2010); Ito and Inatomi (2012) \\
\hline De Visscher model & No & Yes & No & De Visscher and Van Cleemput (2003) \\
\hline Walter model & Yes & Yes & Yes & Walter and Heimann (2000); Walter et al. (1996) \\
\hline Xu model & Yes & Yes & Yes & Xu et al. (2007) \\
\hline
\end{tabular}

production from hydrogen $\left(\mathrm{H}_{2}\right)$ and carbon dioxide $\left(\mathrm{CO}_{2}\right)$. Acetoclastic and hydrogenotrophic methanogenesis account for $\sim 50-90$ and $\sim 10-43 \%$ of global annual $\mathrm{CH}_{4}$ produced, respectively (Conrad and Klose, 1999; Kotsyurbenko et al., 2004; Mer and Roger, 2001; Summons et al., 1998). Methylotrophic methanogenesis (producing $\mathrm{CH}_{4}$ from methanol, methylamines, or dimethylsulfide) is usually considered a minor contributor of $\mathrm{CH}_{4}$, but may be significant in marine systems (Summons et al., 1998). The proportion of $\mathrm{CH}_{4}$ produced via any of these pathways varies widely in time, space, and across ecosystem types.

Methanotrophy occurs under aerobic (Gerard and Chanton, 1993) and anaerobic (Smemo and Yavitt, 2011) conditions. These oxidative processes can occur in several locations in soil and plants (Frenzel and Rudolph, 1998; Heil- man and Carlton, 2001, Ström et al., 2005) and using $\mathrm{CH}_{4}$ either produced in the soil column or transported from the atmosphere (Mau et al., 2013). Large variation in the relative magnitudes of these pathways as a percentage of total methanotrophy has been observed: aerobic oxidation of $\mathrm{CH}_{4}$ in soil contributes 1-90\% (King, 1996; Ström et al., 2005), anaerobic oxidation of $\mathrm{CH}_{4}$ within the soil profile contributes $0.3-5 \%$ (Blazewicz et al., 2012; Murase and Kimura, 1996), oxidation of $\mathrm{CH}_{4}$ during transport in plant aerenchyma contributes < $1 \%$ (Frenzel and Karofeld, 2000; Frenzel and Rudolph, 1998), and oxidation of atmospheric $\mathrm{CH}_{4}$ contributes $\sim 10-100 \%$ (ranging from $\sim 10 \%$ for wetland to $\sim 100 \%$ for upland) (Gulledge and Schimel, 1998a, b; Topp and Pattey, 1997) to total methanotrophy in the ecosystem. $\mathrm{CH}_{4}$ is transported from the soil profile to the at- 
mosphere in typical open-water wetlands by seven pathways that could be aggregated into three: plant-mediated transport accounts for 12-98\% (Butterbach-Bahl et al., 1997; Mer and Roger, 2001; Morrissey and Livingston, 1992), diffusion accounts for $\sim 5 \%$ for wetlands and $>90 \%$ for upland systems (Barber et al., 1988; Mer and Roger, 2001), and ebullition accounts for 10-60\% (Chanton et al., 1989; Tokida et al., 2007) of the $\mathrm{CH}_{4}$ produced in the soil that is emitted into the atmosphere. The plant-mediated transport includes diffusive and advective (associated with gas or liquid flow) transports; soil matrix transport includes soil gaseous diffusion and advection and aqueous diffusion and advection. Because diffusion normally dominates soil matrix transport, we only consider here the model's representation of diffusion, consistent with other studies (Mer and Roger, 2001; Bridgham et al., 2013).

Environmental factors affecting $\mathrm{CH}_{4}$ processes have many direct and indirect controls. The dominant direct factors controlling methanogenesis and methanotrophy in most ecosystems include oxygen availability, dissolved organic carbon concentration, soil $\mathrm{pH}$, soil temperature, soil moisture, nitrate and other reducers, ferric iron, microbial community structure, active microbial biomass, wind speed (Askaer et al., 2011), plant root structure (Nouchi et al., 1990), etc. Indirect factors include soil texture and mineralogy, vegetation, air temperature, soil fauna, nitrogen input, irrigation, agricultural practices, sulfate reduction, and carbon quality (Banger et al., 2012; Bridgham et al., 2013; Hanson and Hanson, 1996; Higgins et al., 1981; Mer and Roger, 2001). The complicated effects induced by a few key factors in $\mathrm{CH}_{4}$ processes have been mathematically described and incorporated into many $\mathrm{CH}_{4}$ models, for example, direct factors such as soil temperature, moisture, oxygen availability, soil $\mathrm{pH}$, and soil redox potential (Grant, 1998; Riley et al., 2011; Tian et al., 2010; Zhuang et al., 2004). The indirect factors such as nitrogen input (Banger et al., 2012), irrigation (Wassmann et al., 2000), and agricultural practices were not reviewed in this study as their impacts are indirect and were modeled through impacts on vegetation and hydrology (Li, 2000; Ren et al., 2011; Xu et al., 2010).

\section{Model representation of $\mathrm{CH}_{4}$ processes}

We reviewed $40 \mathrm{CH}_{4}$ models (Fig. 1 and Table 1), which were developed for a variety of purposes. The first $\mathrm{CH}_{4}$ model was published in 1986 by Lovley and Klug (1986) to simulate methanogenesis in freshwater sediments, and since then a number of $\mathrm{CH}_{4}$ models have been developed and applied at numerous scales (Table 1). For example, Cao et al. (1995) developed the Methane Emission Model (MEM) and applied it to quantify the global $\mathrm{CH}_{4}$ source in rice paddies and the sensitivity of the global $\mathrm{CH}_{4}$ budget's response to climate change (Cao et al., 1995, 1998). Grant et al. (1998) developed the ecosys model, which is currently the ecosystem-scale model that most mechanistically represents

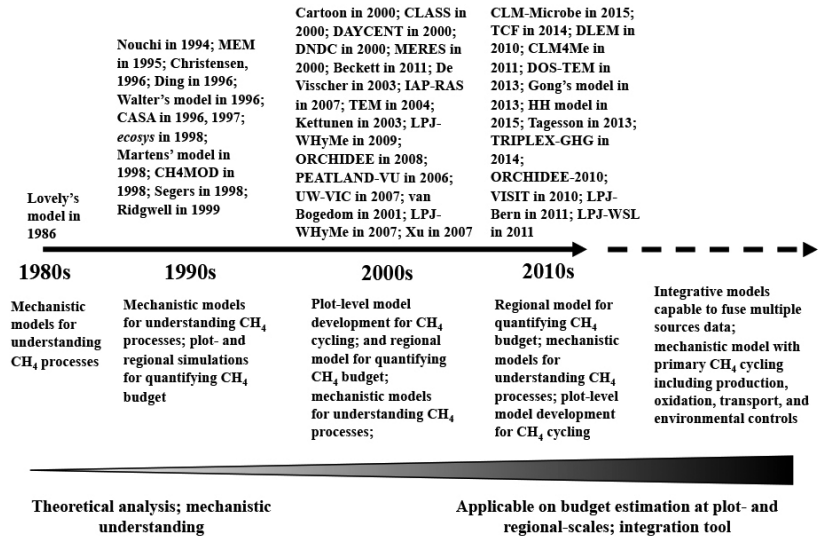

Figure 1. Published $\mathrm{CH}_{4}$ models and modeling trends in terms of applicability and mechanistic representation of $\mathrm{CH}_{4}$ cycling processes over recent decades; the envisioned $\mathrm{CH}_{4}$ model capability.

the many kinetic processes and microbial mechanisms for methanogenesis, methanotrophy, and $\mathrm{CH}_{4}$ emission (Grant and Roulet, 2002). Riley et al. (2011) developed CLM4Me, a $\mathrm{CH}_{4}$ module for the Community Land Model, which is incorporated into the Community Earth System Model. The family of LPJ models (LPJ-Bern, LPJ-WHyMe, LPJ-WSL) was developed under the LPJ framework to simulate $\mathrm{CH}_{4}$ processes, but with different modules for $\mathrm{CH}_{4}$ cycling; for example, LPJ-Bern and LPJ-WHyMe incorporate the Walter $\mathrm{CH}_{4}$ module (Walter and Heimann, 2000; Walter et al., 1996; Wania et al., 2009), while LPJ-WSL incorporates the $\mathrm{CH}_{4}$ module from Christensen et al. (1996). The number of $\mathrm{CH}_{4}$ models has steadily increased since the 1980s (Fig. 1): 1 in the 1980s, 11 in the 1990s, 14 in the 2000s, and 14 for 2010-2015. This increase in model developments is driven by many factors, including a desire to understand the contribution of $\mathrm{CH}_{4}$ processes to the regional $\mathrm{CH}_{4}$ budget (Fig. 1). For instance, Lovley's model was built to understand the $\mathrm{CH}_{4}$ production and sulfate reduction in freshwater sediment (Lovley and Klug, 1986); while all models published in the 2010s are applicable for $\mathrm{CH}_{4}$ budget quantification, particularly at regional scale. This rapid increase in $\mathrm{CH}_{4}$ model development indicates a growing effort to analyze $\mathrm{CH}_{4}$ cycling and quantify $\mathrm{CH}_{4}$ budgets across spatial scales. Meanwhile, the key mechanisms represented in the models have increased at a slower pace (Fig. 2). The most important changes are representation of vertically resolved processes within the soil and regional model simulation. For example, the percentage of the newly developed models with vertically resolved $\mathrm{CH}_{4}$ biogeochemistry has increased from $54 \%$ before 2000 to $\sim 79 \%$ in the most recent decade (2010-2015). The proportion of models with regional simulation capability (producing a spatial map of $\mathrm{CH}_{4}$ fluxes with inputs of spatial map of driving forces) has doubled from $\sim 50 \%$ before the 2010s to almost $100 \%$ afterwards (Fig. 2). 
Table 2. Key mechanisms/features of $\mathrm{CH}_{4}$ processes and their representations in $\mathrm{CH}_{4}$ models.

\begin{tabular}{|c|c|}
\hline Key mechanisms & Models \\
\hline Methanogenesis & $\begin{array}{l}\text { Cartoon model, CASA, CH4MOD, Christensen model, CLM4Me, CLM-Microbe, Ding model, } \\
\text { DLEM, DNDC, DOS-TEM, ecosys, Gong model, IAP-RAS, Kettunen model, Lovley model, } \\
\text { LPJ-Brn, LPJ-WHyMe, LPJ-WSL, Martens model, MEM, MERES, ORCHIDEE, SDGVM, } \\
\text { Segers model, TCF, TEM, TRIPLEX-GHG, UW-VIC, van Bodegom's model, VISIT, Walter } \\
\text { model, Xu's model }\end{array}$ \\
\hline Methanotrophy & $\begin{array}{l}\text { Cartoon model, CASA, CLASS, CLM4Me, CLM- Microbe, DAYCENT, DLEM, DNDC, } \\
\text { DOS-TEM, ecosys, Gong model, Kettunen model, LPJ-Bern, LPJ-WHyMe, Martens model, } \\
\text { MEM, MERES, ORCHIDEE, Ridgwells model, SDGVM, Segers model, TCF, TEM, } \\
\text { TRIPLEX-GHG, UW-VIC, van Bodegom's model, VISIT, De Visscher model, Walter model, } \\
\text { Xu model }\end{array}$ \\
\hline Anaerobic oxidation of $\mathrm{CH}_{4}$ & CLM-Microbe, Martens model \\
\hline Substrate (acetate/DOC) & $\begin{array}{l}\text { CH4MOD, CLM-Microbe, DLEM, DNDC, ecosys, Gong model, Kettunen model, Lovley } \\
\text { model, Martens model, MEM, MERES, SDGVM, Segers model, TCF, van Bodegom model, } \\
\text { Xu model }\end{array}$ \\
\hline Microbial functional groups & CLM-Microbe, ecosys, Segers model \\
\hline $\mathrm{CH}_{4}$ storage in soil profile & $\begin{array}{l}\text { Beckett model, Cartoon model, CLM4Me, CLM-Microbe, ecosys, Kettunen model, Martens } \\
\text { model, MERES, Nouchi model, ORCHIDEE, Segers model, UW-VIC, van Bodegom model, } \\
\text { VISIT, De Visscher model, Walter model }\end{array}$ \\
\hline $\mathrm{O}_{2}$ availability for $\mathrm{CH}_{4}$ oxidation & $\begin{array}{l}\text { Beckett model, Cartoon model, CLM4Me, CLM-Microbe, ecosys, Kettunen model, MERES, } \\
\text { Segers model, van Bodegom model, De Visscher model, Xu model }\end{array}$ \\
\hline Iron biogeochemistry & van Bodegom model \\
\hline Sulfate biogeochemistry & Lovley model, Martens model, van Bodegom model \\
\hline Frozen trapped $\mathrm{CH}_{4}$ & None \\
\hline Embedded in the Earth system model & CLASS, CLM4Me, CLM-Microbe, IAP-RAS, ORCHIDEE, SDGVM \\
\hline Vertical resolved biogeochemistry & $\begin{array}{l}\text { Beckett model, Cartoon model, CLASS, CLM4Me, CLM-Microbe, DNDC, DOS-TEM, } \\
\text { ecosys, Gong model, HH model, IAP-RAS, Kettunen model, Lovley model, LPJ-Bern, LPJ- } \\
\text { WHyMe, LPJ-WSL, Martens model, MERES, ORCHIDEE, Ridgwell model, SDGVM, Seger } \\
\text { model, TRIPLEX-GHG, UW-VIC, VISIT, De Visscher model, Walter model, Xu model }\end{array}$ \\
\hline Regional-scale, capacity for up-scaling & $\begin{array}{l}\text { CASA, CH4MOD, Christensen model, CLASS, CLM4Me, CLM-Microbe, DAYCENT, } \\
\text { DLEM, ecosys, Gong model, HH model, IAP-RAS, LPJ-Bern, LPJ-WHyMe, LPJ-WSL, } \\
\text { Martens model, MEM, MERES, ORCHIDEE, Ridgwell model, SDGVM, Tagesson model, } \\
\text { TCF, TEM, TRIPLEX-GHG, UW-VIC, VISIT, Walter model }\end{array}$ \\
\hline
\end{tabular}

The majority of these models were designed to simulate land-surface exchange in saturated ecosystems (primarily natural wetlands and rice paddies) (Huang et al., 1998b; Li, 2000; Walter et al., 1996) (Table 1). Not all of the models explicitly represented the belowground mechanistic processes for $\mathrm{CH}_{4}$ production and consumption and the primary carbon biogeochemical processes (Christensen et al., 1996; Ding and Wang, 1996). The land-atmosphere $\mathrm{CH}_{4}$ exchange is a net balance of many processes, including production, oxidation, and transport, which are represented in models with different complexities (Table 2). Some models are quite complicated, while some are relatively simple. The obvious tradeoff in modeling $\mathrm{CH}_{4}$ cycling is to represent mechanisms as accurately as possible while managing complexity (Evans et al., 2013), and ensuring that additional complexity enhances predictability (Tang and Zhuang, 2008).

\section{1 $\mathrm{CH}_{4}$ model classification}

Based on a cluster analysis that considers model characteristics including acetoclastic methanogenesis, hydrogenotrophic methanogenesis, methanotrophy, different $\mathrm{CH}_{4}$ transport pathways, multiple soil layers, and oxygen availability, current $\mathrm{CH}_{4}$ models can be classified into three groups (Figs. 3 and 4). The first group of $\mathrm{CH}_{4}$ models uses a very simple framework for land-surface $\mathrm{CH}_{4}$ flux, and most were developed before the 2000s (Christensen's model, CASA, etc.) (Fig. 4a). These models treated landsurface $\mathrm{CH}_{4}$ flux as an empirical function and link it to environmental controls or soil organic carbon. This group of models ignored the mechanistic processes of methanogenesis, methanotrophy, and $\mathrm{CH}_{4}$ transport. The second group of $\mathrm{CH}_{4}$ models considers processes in a relatively simple manner (one or two primary $\mathrm{CH}_{4}$ transport pathways, methanogenesis as a function of DOC (dissolved organic carbon), oxidation of atmospheric $\mathrm{CH}_{4}$, etc.); however, the methanogenesis and methanotrophy mechanisms are still 


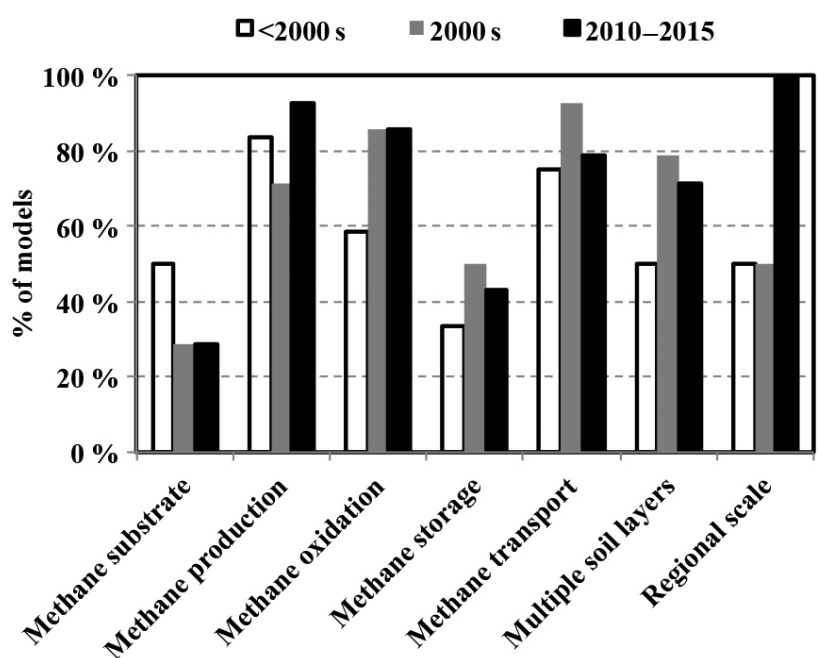

Figure 2. Percentage of $\mathrm{CH}_{4}$ models with consideration of some key $\mathrm{CH}_{4}$ mechanisms. The percentage was calculated as the number of models considering each mechanism divided by the total number of published models in each time period.

not mechanistically represented (Fig. 4b). For example, DLEM simulates $\mathrm{CH}_{4}$ production with a Michaelis-Menten equation with DOC concentration as substrate (Tian et al., 2010); Walter's model simulates $\mathrm{CH}_{4}$ production with a simple multiplier between substrate availability and environmental scalars and $\mathrm{CH}_{4}$ oxidation with a Michaelis-Menten equation (Walter et al., 1996). The third group of $\mathrm{CH}_{4}$ models explicitly simulates the processes for methanogenesis, methanotrophy, and $\mathrm{CH}_{4}$ transport as well as their environmental controls, which allows comprehensive investigation of physical, chemical, or biological processes' contribution to land-surface $\mathrm{CH}_{4}$ flux (Fig. 4c). Of the models in the third group, none fully represents all these processes (although some have most of the features described); for example, the ecosys model is one of the few models to represent most of the $\mathrm{CH}_{4}$ cycling processes shown in Fig. 4c, although it has not been embedded in an Earth system model.

\subsection{Methanogenesis}

Models make use of four types of modeling frameworks (Table 3) to relate methanogenesis to substrate requirements. Similar to Eqs. (1)-(4) in Table 3, there are four model algorithms to represent methanogenesis: (1) empirical association between methanogenesis and environmental condition, including temperature and water table; (2) empirical correlation of methanogenesis with biological variables (particularly heterotrophic respiration and soil organic matter); (3) methanogenesis as a function of DOC concentration; and (4) a suite of mechanistic processes simulated for methanogenesis.

Representation of the substrate for methanogenesis may be a key aspect of simulating $\mathrm{CH}_{4}$ cycling in terrestrial ecosys-

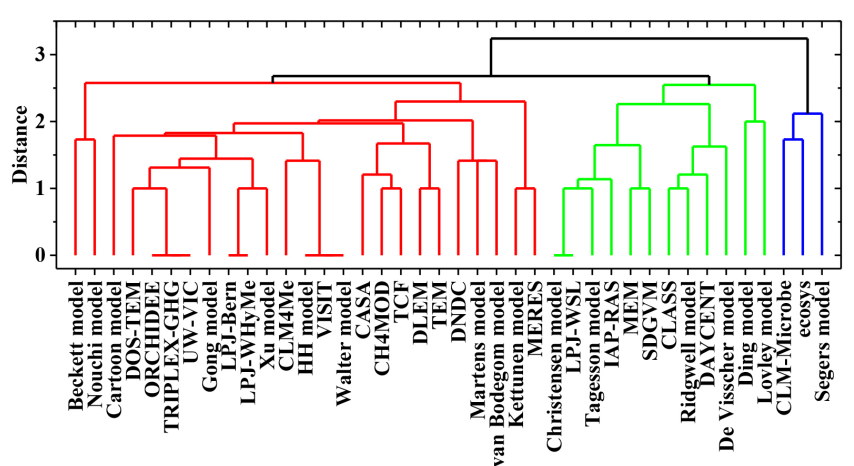

Figure 3. Cluster analysis showing three groups of $\mathrm{CH}_{4}$ models based on model characteristics (lines with the same color indicate $\mathrm{CH}_{4}$ models in the same group; green lines represent a relatively simple model structure, red lines represent relatively mechanistic models, and blue lines represent mechanistic models).

(a)

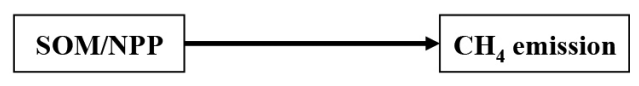

(b)

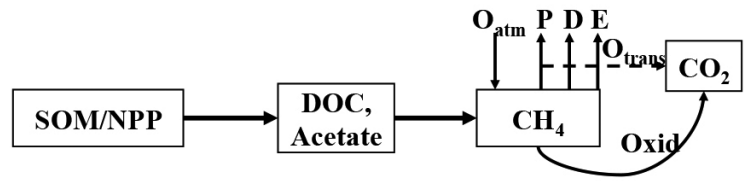

(c)

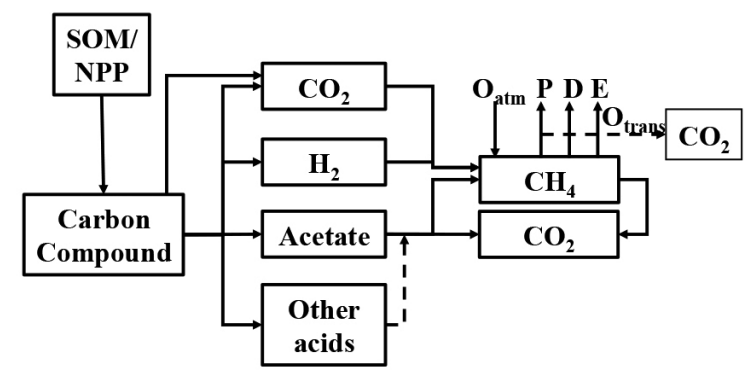

Figure 4. Three types of models with key mechanisms for $\mathrm{CH}_{4}$ production and oxidation (SOM: soil organic matter; NPP: net primary production; DOC: dissolved organic carbon; $O_{\mathrm{atm}}$ : oxidation of atmospheric $\mathrm{CH}_{4} ; P$ : plant-mediated transport; $D$ : diffusion transport; $E$ : ebullition transport; $O_{\text {xid }}$ : oxidation; $O_{\text {trans }}$ : oxidation of $\mathrm{CH}_{4}$ during transport).

tems (Bellisario et al., 1999); however, more than half of the models examined do not explicitly simulate substrates for methanogenesis. We note, however, that explicit representation of substrates and their effects on methanogenesis requires additional model parameters, and therefore degrees of freedom in the model, which can lead to increased equifinality (Tang and Zhuang, 2008). The optimum complexity level for methanogenesis and consumption models remains to be determined.

The first model algorithm correlates methanogenesis with environmental factors and ignores substrate production and its influence on methanogenesis (Eq. 1) (Table 3). This group includes Christensen's model (Christensen et al., 1996), 
Table 3. The mathematical equations used to describe the $\mathrm{CH}_{4}$ processes used in representative models $\left(P_{\mathrm{CH}_{4}}\right.$ is the $\mathrm{CH}_{4}$ production rate; Oxid $\mathrm{CH}_{4}$ is the $\mathrm{CH}_{4}$ oxidation rate; $T_{\mathrm{CH}_{4}}$ is the $\mathrm{CH}_{4}$ transport rate; $D_{\mathrm{CH}_{4}}$ is the $\mathrm{CH}_{4}$ diffusion rate; some parameters may have been changed from the original publication to keep relative consistentcy in this table).

\begin{tabular}{|c|c|c|c|c|}
\hline $\begin{array}{l}\mathrm{CH}_{4} \\
\text { processes }\end{array}$ & & Equations & Ecological description & Model examples \\
\hline \multirow[t]{5}{*}{$\begin{array}{l}\mathrm{CH}_{4} \text { substrate and } \\
\mathrm{CH}_{4} \text { production }\end{array}$} & 1 & $P_{\mathrm{CH}_{4}}=f(T W)$ & A function of temperature $(T)$ and moisture $(W)$ & $\begin{array}{l}\text { Christensen model, IAP-RAS, } \\
\text { DAYCENT }\end{array}$ \\
\hline & $2 \mathrm{a}$ & $P_{\mathrm{CH}_{4}}=r \times H R \times f(T W)$ & $\begin{array}{l}\text { A portion of heterotrophic respiration, affected by tem- } \\
\text { perature }(T) \text { and moisture }(W)\end{array}$ & $\begin{array}{l}\text { LPJ family, CLM } 4 \text { Me, Ding model, } \\
\text { MERES, TRIPLEX-GHG }\end{array}$ \\
\hline & $2 b$ & $P_{\mathrm{CH}_{4}}=r \times \mathrm{SOM} \times f(T W)$ & $\begin{array}{l}\text { A portion of soil organic matter (SOM), affected by } \\
\text { temperature }(T) \text { and moisture }(W) \text {; Walter's model uses } \\
\text { indirect association with NPP }\end{array}$ & $\begin{array}{l}\text { CH4MOD, DOS-Tem, Gong model, HH } \\
\text { model, Walter model }\end{array}$ \\
\hline & 3 & $P_{\mathrm{CH}_{4}}=V \times \frac{[\mathrm{DOC}]}{K_{\mathrm{DOC}}+[\mathrm{DOC}]} \times f(T W)$ & $\begin{array}{l}\text { A portion of dissolved organic carbon (DOC), affected } \\
\text { by temperature }(T) \text { and moisture }(W)\end{array}$ & MEM, DLEM \\
\hline & 4 & $P_{\mathrm{CH}_{4}}=f\left(\right.$ DOCAcetate, $\left.\mathrm{CO}_{2}\right) \times f(T W)$ & $\begin{array}{l}\text { Mechanistic processes for } \mathrm{CH}_{4} \text { production are consid- } \\
\text { ered, affected by temperature }(T) \text { and moisture }(W)\end{array}$ & $\begin{array}{l}\text { Kettunen model, Segers model, van Bode- } \\
\text { goms model, and ecosys }\end{array}$ \\
\hline \multirow[t]{2}{*}{$\mathrm{CH}_{4}$ oxidation } & 5 & $\operatorname{Oxid}_{\mathrm{CH}_{4}}=V \times\left(\frac{\left[\mathrm{CH}_{4}\right]}{K_{\mathrm{CH}_{4}}+\left[\mathrm{CH}_{4}\right]}\right) \times f(T W)$ & $\begin{array}{l}\text { Oxidation as a function of } \mathrm{CH}_{4} \text { concentration and tem- } \\
\text { perature and moisture }\end{array}$ & DLEM, TRIPLEX-GHG, VISIT \\
\hline & 6 & $\operatorname{Oxid}_{\mathrm{CH}_{4}}=V \times\left(\frac{\left[\mathrm{CH}_{4}\right]}{K_{\mathrm{CH}_{4}+\left[\mathrm{CH}_{4}\right]}}\right)\left(\frac{\left[\mathrm{O}_{2}\right]}{K_{\mathrm{O}_{2}}+\left[\mathrm{O}_{2}\right]}\right) \times f(T W)$ & $\begin{array}{l}\text { Oxidation as a function of } \mathrm{CH}_{4} \text { and } \mathrm{O}_{2} \text { concentration, } \\
\text { temperature and moisture }\end{array}$ & $\begin{array}{l}\text { Cartoon model, CLM4Me, } \\
\text { CLM-Microbe, Kettunen model }\end{array}$ \\
\hline \multirow[t]{4}{*}{$\mathrm{CH}_{4}$ transport } & 7 & $T_{\mathrm{CH}_{4}}=V \times\left(\left[\mathrm{CH}_{4}\right]-\overline{\left[\mathrm{CH}_{4}\right]}\right)$ & $\begin{array}{l}V \text { is the parameter for distance, diffusion coefficient, } \\
\text { etc.; }\left[\mathrm{CH}_{4}\right] \text { is the concentration of } \mathrm{CH}_{4} \text { in the soil/water } \\
\text { profile (dissolvability for DLEM, } 0 \text { for DNDC); and } \\
{\left[\mathrm{CH}_{4}\right] \text { is the threshold of } \mathrm{CH}_{4} \text { concentration above }} \\
\text { which } \mathrm{CH}_{4} \text { will be transported to the atmosphere via } \\
\text { either of the three transport pathways }\end{array}$ & DLEM, DNDC, Walter model \\
\hline & $8 \mathrm{a}$ & $A=\frac{C(z)-C_{a}}{r_{L} z / D+r_{a}} p T \rho_{r}$ & Aerenchyma transport & CLM4Me \\
\hline & $8 b$ & $\begin{array}{l}\text { Moves to first unsaturated layer and then released to gaseous } \\
\text { phase }\end{array}$ & Ebullition & CLM4Me \\
\hline & $8 \mathrm{c}$ & $D_{\mathrm{CH}_{4}}=D \times \frac{\Delta\left[\mathrm{CH}_{4}\right]}{\Delta z}$ & $\begin{array}{l}\text { Diffusion of } \mathrm{CH}_{4} \text { was simulated following Fick's law; } \\
\text { CLM4Me separates aqueous and gaseous diffusion }\end{array}$ & $\begin{array}{l}\text { CLM4Me, CLM-Microbe, ecosys, } \\
\text { Ridgwell model, TRIPLEX-GHG; Serg- } \\
\text { ers model }\end{array}$ \\
\hline \multirow[t]{4}{*}{ Temperature effects } & 9 & $\begin{array}{l}f(T)=a \times T+b \\
f(T)=a \times T^{2}+b \times T+c \\
f(T)=b \times e^{0.2424 \times T}\end{array}$ & $\begin{array}{l}\text { Linear regression on temperature or degree days; } \\
\text { DNDC simulate temperature impact on production not } \\
\text { on oxidation }\end{array}$ & $\begin{array}{l}\text { DAYCENT, DNDC, IAP-RAS, LPJ fam- } \\
\text { ily }\end{array}$ \\
\hline & 10 & $f(T)=Q_{10}^{\frac{\left(T-T_{\mathrm{ref}}\right)}{10}}$ & $Q_{10}$ equations; $T_{\text {ref }}$ is the reference temperature & $\begin{array}{l}\text { CH4MOD, CLM-Microbe, CLM4Me, } \\
\text { DLEM, VISIT, Kettunen model }\end{array}$ \\
\hline & $11 \mathrm{a}$ & $V_{T}=V^{0} \times \exp \left(\frac{\Delta E}{R}\left[\frac{1}{T^{0}}-\frac{1}{T}\right]\right)$ & Arrhenius equation & Cartoon model, Ding model \\
\hline & $11 \mathrm{~b}$ & $f_{T}=\frac{T_{\mathrm{s}} \times \exp \left(A-\frac{H_{\mathrm{a}}}{R \times T_{\mathrm{s}}}\right)}{\left[1+\exp \left(\frac{H_{\mathrm{d} 1}-S \times T_{\mathrm{s}}}{R \times T_{\mathrm{s}}}\right)+\exp \left(\frac{S \times T_{\mathrm{S}}-H_{\mathrm{dh}}}{R \times T_{\mathrm{s}}}\right)\right]}$ & $\begin{array}{l}\text { Modified Arrhenius equation; } T_{\mathrm{S}} \text { is soil temperature at } \\
K ; A \text { is the parameter for } f_{T}=1.0 \text { at } T_{\mathrm{S}}=303.16 \mathrm{~K} \text {; } \\
H_{\mathrm{a}} \text { is the energy of activation }(\mathrm{J} \mathrm{mol}-1) ; R \text { is universal } \\
\text { gas constant }\left(\mathrm{J} \mathrm{mol}^{-1} \mathrm{~K}^{-1}\right) ; H_{\mathrm{dl}} \text { and } H_{\mathrm{dh}} \text { are energy of } \\
\text { low and high temperature deactivation }\left(\mathrm{J} \mathrm{mol}^{-1}\right)\end{array}$ & ecosys \\
\hline \multirow{5}{*}{$\begin{array}{l}\text { Moisture effects on } \\
\text { methanogenesis and } \\
\text { methanotrophy }\end{array}$} & 12 & $\begin{array}{l}\text { No moisture effect is simulated, rather inundation area is simu- } \\
\text { lated }\end{array}$ & $\begin{array}{l}\text { No equation, while a temporal and spatial variation of } \\
\text { inundation and saturation impacts }\end{array}$ & CASA \\
\hline & 13 & $F_{\vartheta}=e^{-P / P_{c}}$ & $\begin{array}{l}\text { Water stress for oxidation, where } P \text { is soil moisture and } \\
P_{c}=-2.4 \times 10^{5} \mathrm{~mm}\end{array}$ & CLM4Me \\
\hline & 14 & $f(\mathrm{SM})=\left\{\begin{array}{l}1, \varphi>0.2 \mathrm{Mpa} \\
{\left[1-\frac{\log _{10} \varphi-\log _{10}(0.2)}{\log _{10}(100)-\log _{10}(0.2)}\right]^{\beta}, 0.2>=\varphi>=100 \mathrm{Mpa}} \\
0, \varphi>100 \mathrm{Mpa}\end{array}\right.$ & $\beta$ is an arbitrary constant, $\phi$ is the soil water potential & CLASS \\
\hline & 15 & $\begin{array}{l}f_{\text {prod }}(\mathrm{SM})=\left(\frac{\mathrm{SM}-\mathrm{SM}_{\mathrm{fc}}}{\mathrm{SM}_{\mathrm{sat}}-\mathrm{SM}_{\mathrm{fc}}}\right)^{2} \times 0.368 \times e^{\left(\frac{\mathrm{SM}-\mathrm{SM}_{\mathrm{fc}}}{\mathrm{SM}_{\mathrm{sat}}-\mathrm{SM}_{\mathrm{fc}}}\right)} \\
f_{\text {oxid }}(\mathrm{SM})=1-f_{\text {prod }}(\mathrm{SM})\end{array}$ & $\begin{array}{l}\text { Different impacts on } \mathrm{CH}_{4} \text { production and consumption; } \\
\mathrm{SM} \text { : soil moisture; } \mathrm{SM}_{\mathrm{fc}} \text { : field capacity; } \mathrm{SM}_{\mathrm{sat}} \text { : satura- } \\
\text { tion soil moisture }\end{array}$ & DLEM \\
\hline & 16 & $f(\mathrm{SM})=\frac{\left(M_{V}-M_{\min }\right) \times\left(M-M_{\max }\right)}{\left(M_{V}-M_{\min }\right) \times\left(M_{V}-M_{\max }\right)-\left(M_{V}-M_{\mathrm{opt}}\right)^{2}}$ & Bell-shape curve & TEM \\
\hline \multirow[t]{3}{*}{$\mathrm{pH}$ effects } & $17 \mathrm{a}$ & $f(\mathrm{pH})=\frac{\left(\mathrm{pH}-\mathrm{pH}_{\min }\right) \times\left(\mathrm{pH}-\mathrm{pH}_{\max }\right)}{\left(\mathrm{pH}-\mathrm{pH}_{\min }\right) \times\left(\mathrm{pH}-\mathrm{pH}_{\max }\right)-\left(\mathrm{pH}-\mathrm{pH}_{\mathrm{opt}}\right)^{2}}$ & Bell-shape curve & CLM-Microbe, MEM, TEM, \\
\hline & $17 \mathrm{~b}$ & $f(\mathrm{pH})=10^{-0.2335 \times \mathrm{pH}^{2}+2.7727 \times \mathrm{pH}-8.6}$ & Bell-shape curve & CLM4Me \\
\hline & $17 \mathrm{c}$ & $f(\mathrm{pH})= \begin{cases}0 \mathrm{pH} \leq 4 \text { or } \mathrm{pH} \geq 10 & \\
\frac{1.02}{1+1000000 \times e^{(-2.5 \times \mathrm{pH})}} & 4>\mathrm{pH}>7 \\
\frac{1.02}{1+1000000 \times e^{(-2.5 \times(14-\mathrm{pH}))}} 7>\mathrm{pH}>10\end{cases}$ & Bell-shape curve & DLEM \\
\hline
\end{tabular}


which simulates the net flux of $\mathrm{CH}_{4}$ based on fraction of saturated soil column and soil temperature, and the IAP-RAS model (Mokhov et al., 2007), which calculates methanogenesis as an empirical equation of soil temperature. This group has a role in site-specific interpolation of observations for scaling over time at a given site, but does not explicitly represent carbon or acetate substrate. The second model algorithm directly links methanogenesis with heterotrophic respiration or soil organic matter content, but does not explicitly represent carbon or acetate substrate availability (Eq. 2); examples are the LPJ model family (Hodson et al., 2011; Spahni et al., 2011; Wania et al., 2009, 2010) and CLM4Me (Riley et al., 2011). The third model algorithm simulates dissolved organic carbon (DOC) or different pools of soil organic carbon, which are treated as a substrate pool influencing $\mathrm{CH}_{4}$ production (Eq. 3); examples are the MEM (Cao et al., 1995, 1998) and DLEM (Tian et al., 2010). The fourth model algorithm considers the primary substrates for methanogenesis, that is, acetate and single-carbon compounds (Eq. 4); examples are Kettunen's model (Kettunen, 2003), Segers' model (Segers and Kengen, 1998; Segers and Leffelaar, 2001a, b; Segers et al., 2001), van Bodegom's model (van Bodegom et al., 2000, 2001), and the ecosys model (Grant, 1998).

Methanogenesis is a fundamental process for $\mathrm{CH}_{4}$ cycling, and the majority of models simulate methanogenesis in either implicit or explicit ways (Tables 2 and 3). For example, 32 models (i.e., Cartoon model, CASA, CH4MOD, Christensen model, CLM4Me, Ding model, DLEM, DNDC, DOSTEM, ecosys, Gong model, HH model, IAP-RAS, Kettunen model, Lovley model, LPJ-Brn, LPJ-WHyMe, LPJ-WSL, Martens model, MEM, MERES, ORCHIDEE, SDGVM, Segers model, TCF, TEM, TRIPLEX-GHG, UW-VIC, van Bodegom model, VISIT, Walter model, and Xu model) simulate methanogenesis as one individual process. As a comparison, only 3 out of $40 \mathrm{CH}_{4}$ models reviewed explicitly simulate two methanogenesis pathways (acetoclastic methanogenesis and hydrogenotrophic methanogenesis) (Table 3). As mentioned earlier, it is well recognized that there are two dominant methanogenesis pathways, and their relative combination changes significantly across environmental gradients, for example, along the soil profile (Falz et al., 1999) and across landscape types (McCalley et al., 2014). This lack of representation of two methanogenesis mechanisms might have caused dramatic bias in simulating $\mathrm{CH}_{4}$ flux temporally and spatially and needs to be addressed in future model improvements.

Michaelis-Menten-like equations, widely used for simulating $\mathrm{CH}_{4}$ production and oxidation, consider substrates limiting factors (Segers and Kengen, 1998). A few $\mathrm{CH}_{4}$ models in the third category of methanogenesis models (linking methanogenesis with a substrate) use the Michaelis-Mentenlike equation to compute methanogenesis and methanotrophy rates (Eqs. 3, 5, and 6). For example, DLEM simulates methanogenesis as a function of DOC concentration and other environmental controls, and Michaelis-Menten- like functions were used to compute methanogenesis on the basis of DOC as a substrate.

\subsection{Methanotrophy}

Methanotrophy is another important process for simulating the land-atmosphere exchange of $\mathrm{CH}_{4}$ (Table 2). Aerobic and anaerobic methanotrophy occurs in different locations in the soil profile, and affects both methanogenesis in the profile and $\mathrm{CH}_{4}$ diffusing in from the atmosphere. For example, the oxidation of atmospheric $\mathrm{CH}_{4}$, rhizosphere and bulk soil oxidation, and oxidation during $\mathrm{CH}_{4}$ transport from soil to the atmosphere have been measured and modeled (Tables 1 and 2). Anaerobic $\mathrm{CH}_{4}$ oxidation has been measured (Blazewicz et al., 2012) and has been proposed to be incorporated into ecosystem models (Gauthier et al., 2015).

It has been confirmed that the aerobic oxidation of $\mathrm{CH}_{4}$ produced in the soil profile and aerobic oxidation of atmospheric $\mathrm{CH}_{4}$ play a major role in $\mathrm{CH}_{4}$ consumption in the system, and that anaerobic oxidation of $\mathrm{CH}_{4}$ is a minor contributor. Currently, no models explicitly simulate the anaerobic oxidation of $\mathrm{CH}_{4}$ in soil, although a few recent studies highlighted the importance of this process (Blazewicz et al., 2012; Caldwell et al., 2008; Conrad, 2009; Smemo and Yavitt, 2011; Valentine and Reeburgh, 2000). The key reasons for this omission are that the process has not been mathematically described, the key parameters are uncertain (Gauthier et al., 2015), and the biochemical mechanism is not fully understood.

Methanotrophy has been simulated with dual Monod Michaelis-Menten-like equations with $\mathrm{CH}_{4}$ and oxygen as limiting factors (Table 3). Recent work has shown that the Michaelis-Menten approach may be inaccurate when representing multi-substrate, multi-consumer networks, and that a new approach (called equilibrium chemistry approximation, ECA) can ameliorate this problem (Tang and Riley, 2013, 2014; Zhu et al., 2016). Although the ECA approach has not been applied for simulations of $\mathrm{CH}_{4}$ emissions, $\mathrm{CH}_{4} \mathrm{dy}-$ namics are inherently multi-consumer, including transformations associated with methanogens, heterotrophs, ebullition, advection, diffusion, and aerenchyma transport, even if only one substrate is considered.

\section{4 $\mathrm{CH}_{4}$ within the soil/water profile}

$\mathrm{CH}_{4}$ produced in the soil profile or below the water table is not transported immediately into the atmosphere. The time required for $\mathrm{CH}_{4}$ to migrate from a deep soil profile to the atmosphere ranges from minutes to days (depending on temperature, water, soil texture, and emissivity of plant roots), or even a season if the surface is frozen. The majority of current $\mathrm{CH}_{4}$ models assume that $\mathrm{CH}_{4}$ transport to the atmosphere occurs immediately after $\mathrm{CH}_{4}$ is produced, and a portion is oxidized (Tian et al., 2010; Fan et al., 2013); for models sim- 
ulating $\mathrm{CH}_{4}$ flux over minutes to days, the lack of modeled transport may produce unrealistic simulations.

Some models do simulate $\mathrm{CH}_{4}$ dynamics within the soil and water profile (e.g., ecosys, CLM4Me), which produces a lag between methanogenesis and emission, allowing for oxidation to be explicitly represented during transport, and is valuable for simulating the seasonality of $\mathrm{CH}_{4}$ flux (Table 2). For example, the recently observed $\mathrm{CH}_{4}$ burst in the spring season in some field experiments confirms that the storage of $\mathrm{CH}_{4}$ produced in winter can produce a strong emission outburst (Song et al., 2012). Without understanding the mechanism of $\mathrm{CH}_{4}$ storage beneath the soil surface, this phenomenon will be difficult to simulate. In most of the models considering $\mathrm{CH}_{4}$ storage, the $\mathrm{CH}_{4}$ is treated as a simple gas pool, under the water table, which will be transported to the atmosphere through several transport pathways.

\section{5 $\mathrm{CH}_{4}$ transport from soil to the atmosphere}

The transport of $\mathrm{CH}_{4}$ produced and stored in the soil column is the bottleneck for $\mathrm{CH}_{4}$ leaving the system; therefore, this process is an important control on the instantaneous landsurface $\mathrm{CH}_{4}$ flux. Several important pathways of $\mathrm{CH}_{4}$ transport to the atmosphere are identified: plant-mediated diffusive and advective transport, aqueous and gaseous diffusion, and ebullition (Beckett et al., 2001; Chanton, 2005; Mer and Roger, 2001; Whiting and Chanton, 1996). Model simulation of these transport pathways uses direct control of simulated land-surface $\mathrm{CH}_{4}$ flux, with $\mathrm{CH}_{4}$ transport simulation considered in a manner similar to Eq. (7) (Table 3).

The majority $(83 \%)$ of the current models simulate at least one transport pathway. Specifically, $70 \%$ of the models simulate $\mathrm{CH}_{4}$ transport via aerenchyma, $80 \%$ simulate gaseous diffusive transport, and $60 \%$ simulate ebullition transport (Table 1). More than $50 \%$ of models simulated these three transport pathways. Some models simulate explicitly the aqueous and gaseous diffusion of $\mathrm{CH}_{4}$ (Riley et al., 2011), while most models do not simulate advective transport. Many models simulate diffusion and plant-mediated transport in very simple ways. For model improvement in this area, three issues remain as challenges.

Most models treat transport implicitly; for example, the diffusion processes are treated simply as an excessive release of $\mathrm{CH}_{4}$ when its concentration exceeds a threshold (Tian et al., 2010). This treatment prevents the model from simulating the lag between methanogenesis and its final release into the atmosphere, which has been confirmed to be the key mechanism for hot moments and hotspots of $\mathrm{CH}_{4}$ flux (Song et al., 2012) and for oxidation during transport.

The parameters for plant species capable of transporting gas (i.e., aerenchyma) are poorly constrained (Riley et al., 2011), although plant-mediated transport has been identified as the dominant pathway for $\mathrm{CH}_{4}$ emission in some natural wetlands (Aulakh et al., 2000; Colmer, 2003).
Simultaneously representing aqueous and gaseous phases of $\mathrm{CH}_{4}$ is one potentially important issue for simulating $\mathrm{CH}_{4}$ transport from soil to the atmosphere (Tang and Riley, 2014). However, these processes are only explicitly represented in a few extant $\mathrm{CH}_{4}$ models (Riley et al., 2011; Grant et al., 1998).

\subsection{Environmental controls on $\mathrm{CH}_{4}$ processes}

Although a suite of environmental factors affects various $\mathrm{CH}_{4}$ processes, many of these factors are not explicitly simulated in many models. These factors include soil temperature, soil moisture, substrate, soil $\mathrm{pH}$, soil redox potential, and oxygen availability. Many other factors not incorporated into the models could indirectly affect $\mathrm{CH}_{4}$ cycling. For example, nitrogen fertilizer affects methanogenesis through its stimulating impacts on ecosystem productivity, which in turn affects DOC, soil moisture and soil temperature (Xu et al., 2010). The CLM4Me model simulates permafrost and its effects on $\mathrm{CH}_{4}$ dynamics, and has a simple relationship for soil pH impacts on methanogenesis (Riley et al., 2011). Wania et al. (2013) reviewed a number of active $\mathrm{CH}_{4}$ models for their representation of $\mathrm{CH}_{4}$ production area. In this review, we specifically focus on temperature, moisture, and $\mathrm{pH}$ because these factors directly affect $\mathrm{CH}_{4}$ processes in all environments, and they have been explicitly simulated in many of the models.

Three types of mathematical functions have been used to simulate the temperature dependence of $\mathrm{CH}_{4}$ processes: (1) linear functions of air or soil temperature (Eq. 9 in Table 3), (2) the $Q_{10}$ function (Eq. 10 in Table 4), and (3) the Arrhenius type function (Eq. 11 in Table 3). Of these three model representations of temperature dependence, the $Q_{10}$ equation is the most common mathematical description. However, the parameters for these empirical functions vary widely across the models (Table 4). Actual temperature responses may diverge significantly from the models at low temperatures, close to the freezing point of water, and high temperatures, close to the denaturation point of enzymes.

Soil moisture is an important factor controlling $\mathrm{CH}_{4}$ processes, because water limits $\mathrm{O}_{2}$ diffusion from the air through the soil column and because microbes can become stressed at low matric potential. $\mathrm{CH}_{4}$ is produced typically under conditions with a low reduction potential, which is normally associated with long-term inundation. Although methanogenesis occurs solely under reducing conditions (methanogenesis within plant biomass under aerobic condition has never been simulated, although it has been reported in experiments; Keppler et al., 2006), methanotrophy occurs under drier, aerobic conditions. A low water content can also limit microbial activity in frozen soils or soils with high osmolarity (Watanabe and Ito, 2008). Therefore, soil moisture has different impacts on different $\mathrm{CH}_{4}$ processes. Four types of model representation are used to simulate moisture effects on $\mathrm{CH}_{4}$ processes (Eqs. 13-16 in Table 3). 
Table 4. Temperature dependence of $\mathrm{CH}_{4}$ processes in various models (blank indicates the $Q_{10}$ function is not used; all temperatures are expressed as ${ }^{\circ} \mathrm{C} ; 273.15$ was used for unit conversion).

\begin{tabular}{|c|c|c|c|c|}
\hline Model & $Q_{10}$ & Reference temperature $\left({ }^{\circ} \mathrm{C}\right)$ & Note & Sources \\
\hline CASA & & & $\begin{array}{l}\text { Based on a linear equation with tem- } \\
\text { perature }\end{array}$ & Potter (1997) \\
\hline DAYCENT & & & Linear equation $y=0.209 \times T+0.845$ & Del Grosso et al. (2000) \\
\hline LPJ family & & & Linear function was used for tempera- & Hodson et al. (2011); Spahni et al. (2011); \\
\hline LPJ-Bern & & & ture impacts on diffusion. & Wania (2007) \\
\hline \multicolumn{5}{|l|}{ LPJ- } \\
\hline \multicolumn{5}{|l|}{ WHyMe } \\
\hline LPJ-WSL & & & & \\
\hline $\begin{array}{l}\text { Christensen's } \\
\text { model }\end{array}$ & 2 & 2 & $\begin{array}{l}\text { For temperature }>0 \text {, the temperature } \\
\text { impact is set to zero when }<0 \text {. }\end{array}$ & Christensen and Cox (1995) \\
\hline CH4MOD & 3 & 30 & $T=30$ for $30<T \leq 40$ & Huang et al. (1998b) \\
\hline CLM4Me & 2 for production, 1.9 for oxidation & 22 & Parameters for baseline simulation & Riley et al. (2011) \\
\hline $\begin{array}{l}\text { CLM- } \\
\text { Microbe }\end{array}$ & 1.5 & 13.5 & & Xu et al. (2015) \\
\hline DLEM & 2.5 & 30 & $\begin{array}{l}\text { For a temperature range of }[-5,30] \\
\text { temperature impact is set to zero when } \\
<-5 \text { or }>30 \text {. }\end{array}$ & Tian et al. (2010) \\
\hline $\begin{array}{l}\text { Kettunenn's } \\
\text { model }\end{array}$ & 4.0 for production, 2.0 for oxidation & 10 & Standard $Q_{10}$ function & Kettunen (2003) \\
\hline ORCHIDEE & $\begin{array}{l}\text { Abisko site, 2.6; Michigan site, } 3.2 \text {; } \\
\text { Panama site, } 1.2\end{array}$ & Mean annual temperature & $\begin{array}{l}Q_{10} \text { function with different parameters } \\
\text { across biomes }\end{array}$ & Ringeval et al. (2010) \\
\hline TEM & $\begin{array}{l}\text { Alpine tundra: wetland, } 3.5 \text {; upland, } 0.8 \text {. } \\
\text { Wet tundra: wetland, } 2.2 \text {; upland, 1.1. Bo- } \\
\text { real forest: wetland, 1.9; upland, 1.5 }\end{array}$ & $\begin{array}{l}\text { Alpine tundra: wetland, }-3.0 \text {; upland, } \\
\text { 8.0. Wet tundra: wetland, }-5.5 \text {; upland, } \\
\text { 8.0. Boreal forest: wetland, } 1.0 \text {; upland, } \\
7.0\end{array}$ & $\begin{array}{l}Q_{10} \text { function with different parameters } \\
\text { across biomes }\end{array}$ & Zhuang et al. (2004) \\
\hline $\begin{array}{l}\text { TRIPLEX- } \\
\text { GHG }\end{array}$ & $\begin{array}{l}1.7-16 \text { for production, } 1.4-2.4 \text { for oxida- } \\
\text { tion }\end{array}$ & 25 for optimal, 45 for highest temperature & Modified $Q_{10}$ equation & Zhu et al. (2014) \\
\hline VISIT & & Mean annual temperature & & Ito and Inatomi (2012) \\
\hline $\begin{array}{l}\text { Walter's } \\
\text { model }\end{array}$ & 2 & $\begin{array}{l}\text { Ombrotrophic bog, } 12 \text {; poor fen, } 6.5 \text {; olig- } \\
\text { otrophic pine fen, } 3.5 \text {; Arctic tundra, } 0 \text {; } \\
\text { swamp, } 27\end{array}$ & $\begin{array}{l}Q_{10} \text { function with different parameters } \\
\text { across biomes }\end{array}$ & Walter and Heimann (2000) \\
\hline $\begin{array}{l}\text { Cartoon } \\
\text { model }\end{array}$ & & 10 & Arrhenius equation & Arah and Stephen (1998) \\
\hline ecosys & & 30 & Modified Arrhenius equation & Grant et al. (1993) \\
\hline
\end{tabular}

1. Methanogenesis occurs only in the saturated zone and an exponential function for soil moisture is used to control methanotrophy (e.g., CLM4Me).

2. Linear function for moisture impacts (e.g., CLASS use linear function for moisture impact on methanotrophy) (Curry, 2007).

3. Reciprocal responsive curves for moisture impacts on methanogenesis and methanotrophy (e.g., DLEM) (Tian et al., 2010).

4. A bell-shaped curve for methanogenesis (e.g., TEM uses a function similar to Eq. (16) for moisture impacts) (Zhuang et al., 2004).

Soil $\mathrm{pH}$ has been included in a number of $\mathrm{CH}_{4}$ models (Cao et al., 1995; Zhuang et al., 2004). Methanogens and methanotrophs depend on proton and sodium ion translocation for energy conservation; thus, they are directly affected by $\mathrm{pH}$. The $\mathrm{pH}$ impacts on $\mathrm{CH}_{4}$ processes are simulated as a bell-shaped curve although the mathematical functions used to describe $\mathrm{pH}$ impacts are different (Eqs. 17a, b, and c). Moreover, even when the same functions were used in different models, they were associated with different parameter values, indicating slightly different response functions; for example, the MEM model sets $\mathrm{pH}_{\text {min }}$ (minimum $\mathrm{pH}$ value for $\mathrm{CH}_{4}$ processes being active), $\mathrm{pH}_{\mathrm{opt}}$ (optimal $\mathrm{pH}$ value for
$\mathrm{CH}_{4}$ processes being most active), and $\mathrm{pH}_{\max }$ (minimum $\mathrm{pH}$ value for $\mathrm{CH}_{4}$ processes being active) values of 5.5, 7.5, and 9 (Cao et al., 1995). This set of parameter values was adopted in the TEM model (Zhuang et al., 2004), whereas the DLEM model uses values of 4, 7, and 10 (Tian et al., 2010). The CLM4Me model uses a different function while keeping the impact curve at the same shape, but its peak has an optimal $\mathrm{pH}$ of 6.2 (Meng et al., 2012). It should be noted that while $\mathrm{pH}$ has been confirmed to significantly affect $\mathrm{CH}_{4}$ production (Xu et al., 2015), the simulation of $\mathrm{pH}$ dynamics caused by organic acid in soils remains a key challenge for the incorporation of this phenomenon.

For the other environmental factors, model representation is still in its infancy; however, several models consider oxygen availability as an electron acceptor for methanotrophy (e.g., Beckett model, Cartoon model, CLM4Me, ecosys, Kettunen model, MERES, Segers model, van Bodegom model, De Visscher model, and Xu model). In addition, only a few models simulate the impacts of the electron acceptor (nitrate, sulfate, etc.) on $\mathrm{CH}_{4}$ processes (Table 2). For example, the van Bodegom model simulates iron biogeochemistry, and the Lovley model, Marten model, and van Bodegom model all simulate sulfate as the electron acceptor and its impacts on methanogenesis and methanotrophy (Lovley and Klug, 1986; Martens et al., 1998; van Bodegom et al., 2001). Explicitly representing these processes enables future coupling 
of $\mathrm{CH}_{4}$ cycling to processes that are regionally significant, such as iron reduction on the Alaskan North Slope (Miller et al., 2015). These models have the potential advantage of more accurately simulating biogeochemical processes of carbon and ions, although large uncertainties still exist because of the lack of data for constraining model parameters.

\section{7 $\quad \mathrm{CH}_{4}$ implementation in ESMs}

The importance of $\mathrm{CH}_{4}$ flux in simulating climate dynamics has been well recognized (IPCC, 2013; Ringeval et al., 2011), yet few ESMs have implemented a $\mathrm{CH}_{4}$ module (Ringeval et al., 2011; Riley et al., 2011; Xu et al., 2014; Hopcroft et al., 2011; Eliseev et al., 2008). While these models have been claimed to be coupled within ESMs, truly fully coupled simulations within ESMs to evaluate $\mathrm{CH}_{4}$ dynamic impacts on global climate systems are rare (Eliseev et al., 2008; Hopcroft et al., 2011). For example, the SDGVM has been coupled within the Fast Met Office UK Universities Simulator (FAMOUS), a coupled general circulation model, to study the association between terrestrial $\mathrm{CH}_{4}$ fluxes with rapid climate fluctuation during the last glacial period (Hopcroft et al., 2011). The IAP-RAP model was used to simulate terrestrial $\mathrm{CH}_{4}$ flux and its contributions to atmospheric $\mathrm{CH}_{4}$ concentrations and, further on, climate change. The quasi-coupling between ORCHIDEE_WET with an ocean-atmosphere general circulation model was used to theoretically evaluate terrestrial $\mathrm{CH}_{4}$ dynamics on climate systems (Ringeval et al., 2011). The CLM application within the CESM framework has both CLM4Me and CLM-Microbe modules for $\mathrm{CH}_{4}$ dynamics, but none of them have been applied for a fully coupled simulation to evaluate $\mathrm{CH}_{4}$-climate feedback. It should be a key research effort for the CLM community in the next 5 years to complete this coupling. All previous coupled ESM simulations have concluded that changes in terrestrial $\mathrm{CH}_{4}$ flux have small impacts on climate change, while they also pointed out that large uncertainties exist. Given the importance of $\mathrm{CH}_{4}$ as a greenhouse gas and uncertainties in current ESMs in simulating permafrost carbon and $\mathrm{CH}_{4}$ flux, more efforts should be invested to implement the $\mathrm{CH}_{4}$ module in ESMs and further evaluate the $\mathrm{CH}_{4}$-climate feedback under different climate scenarios.

\subsection{Summary}

Through the 4 decades of modeling $\mathrm{CH}_{4}$ cycling in terrestrial ecosystems, consensus has been reached on several fronts. First, $\mathrm{CH}_{4}$ cycling includes a suite of complicated processes, and both the simple and complex models are able to estimate land-surface $\mathrm{CH}_{4}$ flux to a certain level of confidence, although models of different complexity do provide different results (Tang et al., 2010). Second, although a number of $\mathrm{CH}_{4}$ models have been developed, several gaps remain that need new model representations (e.g., dynamic linkage be- tween inundation dynamics and the $\mathrm{CH}_{4}$ module (Melton et al., 2013), and anaerobic oxidation of $\mathrm{CH}_{4}$; Gauthier et al., 2015).

Two recent $\mathrm{CH}_{4}$ model-model inter-comparison projects raised several important points (Bohn et al., 2015; Melton et al., 2013): (1) the distribution of the inundation area is important for accurately simulating global $\mathrm{CH}_{4}$ emissions, but was poorly represented in $\mathrm{CH}_{4}$ models; (2) the modeled response of land-surface $\mathrm{CH}_{4}$ emission to elevated $\mathrm{CO}_{2}$ is likely biased as a number of global change factors were missing, which indicates the need for modeling with multiple global environmental factors; and (3) the need for comparison with high-frequency observational data is identified as an important task for future model-model inter-comparison. These lessons will be helpful for, and likely addressed during, model improvements and applications of more mechanistic $\mathrm{CH}_{4}$ models.

Although the primary individual $\mathrm{CH}_{4}$ processes have been studied and quantified at a certain level of confidence, only a few modeling studies have reported these individual processes as previously discussed. For example, three pathways of $\mathrm{CH}_{4}$ transports were represented in Kettunen (2003) and Walter et al. (1996), but none of those modeled results have been evaluated against observational results for those individual processes. One reason is that measurements rarely distinguish between individual processes; another reason is that the majority of $\mathrm{CH}_{4}$ models do not explicitly represent all processes (Table 2). However, a number of studies report significant shifts in the processes contributing to the surface $\mathrm{CH}_{4}$ flux along environmental gradients or across biomes (Conrad, 2009; Krumholz et al., 1995; McCalley et al., 2014). Projecting $\mathrm{CH}_{4}$ fluxes into future changing climate conditions requires not only accurate simulations of $\mathrm{CH}_{4}$ processes, but also shifts among the various processes. In addition, $\mathrm{CO}_{2}$ flux has been evaluated within the Earth system modeling framework, but only a few studies have evaluated the $\mathrm{CH}_{4}$ flux and its contribution to climate dynamics. Given the much higher warming potential and relatively faster rate of increase in atmospheric $\mathrm{CH}_{4}$, fully coupled simulations are needed to represent the feedbacks between terrestrial $\mathrm{CH}_{4}$ exchanges and climate. We note that a few recent studies reported a relatively small climate warming-methane feedback from global wetlands and permafrost (Gao et al., 2013; Gedney et al., 2004; Riley et al., 2011). A fully mechanistic $\mathrm{CH}_{4}$ model that accounts for all the important features is critically needed. In addition, a modeling framework to integrate multiple sources of data, such as microbial community structure and functional activities, ecosystem-level measurements, and global-scale satellite measurements of gas concentration and flux is needed with these mechanistic $\mathrm{CH}_{4}$ models. 


\section{Needs for mechanistic $\mathrm{CH}_{4}$ models}

During the last few years, the scientific community has continued to improve and optimize models to better simulate methanogenesis, methanotrophy, $\mathrm{CH}_{4}$ transport, and their environmental and biological controls (Xu et al., 2015; Zhu et al., 2014). A number of emerging tasks have been identified, and progress in these directions is expected. First, linking genomic data with large-scale $\mathrm{CH}_{4}$ flux measurements will be an important, while challenging, task for the entire community; for example, some work has been carried out in this direction (De Haas et al., 2011; Larsen et al., 2012). An effort has been initialized to develop a new microbial functional group-based $\mathrm{CH}_{4}$ model, which has the advantages of linking genomic information for each individual process with the four microbial functional groups (Xu et al., 2015). Second, data-data and model-model comparisons are another important effort for model comparison and improvement. One ongoing encouraging feature that all recently developed $\mathrm{CH}_{4}$ models possess is the capability for regional simulations as well as the possibility to be run at the site level (Riley et al., 2011; Zhu et al., 2014).

Third, microbial processes need to be considered for incorporation into ecosystem models for simulating carbon cycling and $\mathrm{CH}_{4}$ processes (DeLong et al., 2011; $\mathrm{Xu}$ et al., 2014). Although a few models explicitly simulate the microbial mechanisms of $\mathrm{CH}_{4}$ cycling (Arah and Stephen, 1998; Grant, 1998; Li, 2000; Segers and Kengen, 1998), none of them have been used for regional- or global-scale estimation of microbial contributions to the $\mathrm{CH}_{4}$ budget. A reasonable experimental design and a well-validated microbial functional group-based $\mathrm{CH}_{4}$ model should be combined to enhance our capability to apply models to estimate a regional $\mathrm{CH}_{4}$ budget and to investigate the combination of microbial and environmental contributions to the land-surface $\mathrm{CH}_{4}$ flux (DeLong et al., 2011). Fourth, incorporating well-validated $\mathrm{CH}_{4}$ modules into Earth system modeling frameworks will allow a fully coupled simulation that provides a holistic understanding of the $\mathrm{CH}_{4}$ processes, with its connections to many other processes and mechanisms in the atmosphere. Several recently developed models fall into the framework of Earth system models (Riley et al., 2011; Ringeval et al., 2010), which provide a foundation for this application in a relatively easy way. This effort will likely contribute not only to the $\mathrm{CH}_{4}$ modeling community, but also to the entire global change science community (Koven et al., 2011). Iron and sulfate biogeochemistry has so far been modeled implicitly by only a few models (Table 2), as mechanisms are as yet poorly understood, and there is a paucity of data. Accordingly, these processes have not been incorporated into recently developed models, and a more explicit inclusion, based on improved biogeochemistry understanding, will hopefully be achieved in the long term.

Based on the above-mentioned needs and model features as well as the mechanisms for the $\mathrm{CH}_{4}$ models, the next gen-

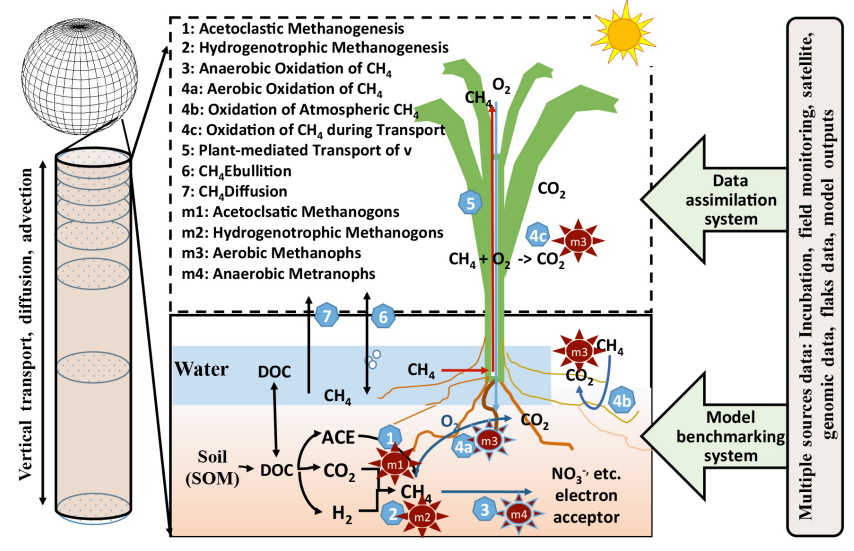

Figure 5. Key features of future mechanistic $\mathrm{CH}_{4}$ models with a full representation of primary $\mathrm{CH}_{4}$ processes in the terrestrial ecosystems. The data assimilation system and model benchmarking system are also shown as auxiliary components of the future $\mathrm{CH}_{4}$ models.

eration of $\mathrm{CH}_{4}$ models will likely include several important features (Fig. 5). The models should (1) be embedded in an Earth system model, (2) consider the vertical distribution of thermal, hydrological, and biogeochemical transport and processes, (3) represent mechanistic processes for microbial $\mathrm{CH}_{4}$ production, consumption, and transport, and (4) support data assimilation and a model benchmarking system as auxiliary components.

\section{Challenges in developing mechanistic $\mathrm{CH}_{4}$ models}

\subsection{Knowledge gaps}

Modeling $\mathrm{CH}_{4}$ cycling is a dynamic process. As new mechanisms are identified, the modeling community should ensure that the mechanisms are well studied and mathematically described, as has occurred over the past decades (Conrad, 1989; McCalley et al., 2014; Schütz et al., 1989; Xu et al., 2015). However, a number of knowledge gaps need to be filled before a full modeling framework of $\mathrm{CH}_{4}$ processes within terrestrial ecosystems can be achieved. The first gap is either confirmation or rejection of a few recently observed $\mathrm{CH}_{4}$ mechanisms; these mechanisms need to be fully vetted before being considered for incorporation into a model. One well-known mechanism still under debate is aerobic $\mathrm{CH}_{4}$ production within plant tissue (Beerling et al., 2008; Keppler et al., 2006). Since its first report in 2006 (Keppler et al., 2006), a few studies have confirmed the mechanism in multiple plant species (Wang et al., 2007). While its existence in nature is still under debate (Dueck et al., 2007), this mechanism will likely not be incorporated into an ecosystem model before solid evidence is presented and consensus is reached. The second new mechanism is $\mathrm{CH}_{4}$ production 
by fungi (Lenhart et al., 2012). More field- or lab-based experiments are needed to investigate this mechanism and its contribution to the global $\mathrm{CH}_{4}$ budget, probably through a data-model integration approach. Third, the aerobic production of $\mathrm{CH}_{4}$ from the cleavage of methylphosphonate has been demonstrated in marine systems (Karl et al., 2008), but the significance of this process in terrestrial systems is unknown. Fourth, the large $\mathrm{CH}_{4}$ emissions from rivers and small ponds are still not fully understood (Holgerson and Raymond, 2016; Martinson et al., 2010), which will likely be a direction for future model improvement.

Another knowledge gap is the missing comprehensive understanding of spatial and temporal variations in $\mathrm{CH}_{4}$ flux; particularly, the "hot spots" and "hot moments" of observed $\mathrm{CH}_{4}$ flux are still not completely understood (Becker et al., 2008; Mastepanov et al., 2008; Song et al., 2012). The traditional static chamber method of measuring $\mathrm{CH}_{4}$ emissions could underestimate the $\mathrm{CH}_{4}$ flux because sparse sampling is unlikely to detect these foci or pulses of unusually high emissions. Better methods are also needed to measure $\mathrm{CH}_{4}$ cycling during the shoulder seasons in the Arctic and subarctic when fluxes may be most variable (Zona et al., 2016). These knowledge gaps are key hurdles for $\mathrm{CH}_{4}$ model development efforts. No model has yet been tested for simulating hotspots or hot moments over large spatial or long temporal scales. However, the high range (usually of factor 1-10) of the observed $\mathrm{CH}_{4}$ flux might cause regional budgets to vary substantially (Song et al., 2012); therefore, mechanistic model representations of these mechanisms are highly needed.

\subsection{Modeling challenges}

Better simulation of $\mathrm{CH}_{4}$ cycling in terrestrial ecosystems requires improvement in the model structure to represent mechanistic $\mathrm{CH}_{4}$ processes. First is the challenge to simulate the vertical profile of soil biogeochemical processes and validate such models with observational results. Although some models have a capability for vertical distribution of carbon and nitrogen (Koven et al., 2013; Tang et al. 2013; Mau et al., 2013), a better framework for $\mathrm{CH}_{4}$ and extension to cover the majority of $\mathrm{CH}_{4}$ models are needed. This vertical distribution of biogeochemistry is necessary for simulating the vertical distribution of $\mathrm{CH}_{4}$ processes and $\mathrm{CH}_{4}$ transport through the soil profile before reaching the atmosphere. A second challenge is incorporating tracer capability. Isotopic tracers $\left({ }^{13} \mathrm{C}\right.$, ${ }^{14} \mathrm{C}$ ) have been widely used for quantifying the carbon flow and partitioning among individual $\mathrm{CH}_{4}$ processes (Conrad, 2005; Conrad and Claus, 2005), but for ecosystem models this capability has not been represented even though it is very important to understanding $\mathrm{CH}_{4}$ processes and integrating field observational data. A third challenge is to simulate microbial functional groups. Microbial processes are carried out by different functional groups of microbes (Lenhart et al., 2012; McCalley et al., 2014). Therefore, model comparison with individual processes requires representing the microbial population sizes (or active biomass) for specific functional groups (Tveit et al., 2015). This goal has proved more difficult than representing plant functional types or traits in models, because not all microbial taxonomic groups have ecologically coherent functions (Philippot et al., 2010). A fourth challenge is to simulate the lateral transport of dissolved and particulate biogeochemical variables that are necessary to better simulate the storage and transport of $\mathrm{CH}_{4}$ within heterogeneous landscapes (Weller et al., 1995). A fifth challenge is modeling $\mathrm{CH}_{4}$ flux across spatial scales. Although a few studies have been used to demonstrate the approach for simulating $\mathrm{CH}_{4}$ budget at plot scale and eddy covariance domain scale (Zhang et al., 2012), a mechanistic framework to link $\mathrm{CH}_{4}$ processes at distinct scales is still lacking, while highly valuable. Finally, a sixth challenge is accurate simulation of $\mathrm{CH}_{4}$ within human-managed ecosystems. Human management practices are always hard to simulate and predict, and their impacts on $\mathrm{CH}_{4}$ processes are challenging ( $\mathrm{Li}$ et al., 2005).

\subsection{Data needs}

First, a comprehensive data set of field measurements of $\mathrm{CH}_{4}$ fluxes across various landscape types is needed to effectively validate the $\mathrm{CH}_{4}$ models. Although a number of data sets have been compiled (Aronson and Helliker, 2010; Chen et al., 2012; Liu and Greaver, 2009; Mosier et al., 1997; Yvon-Durocher et al., 2014), some landscape types are still not fully covered. Meanwhile, high-frequency field observational data are also needed, particularly long-term observational data in some less-studied ecosystems; for example, Arctic tundra ecosystems have been considered an important contributor to the global $\mathrm{CH}_{4}$ budget in the changing climate (IPCC, 2013; Koven et al., 2011); however, a longterm data set of $\mathrm{CH}_{4}$ flux is lacking. It is well known that inter-annual variation of climate may turn an ecosystem from a $\mathrm{CH}_{4}$ sink to a $\mathrm{CH}_{4}$ source (Nauta et al., 2015; Shoemaker et al., 2014); therefore, a long-term observational data set that covers these temporal shifts in $\mathrm{CH}_{4}$ flux and its associated ecosystem information would improve our understanding of the processes and our representation of them in $\mathrm{CH}_{4}$ models. Second, microbial community shifts and their role in $\mathrm{CH}_{4}$ processes are important, although information is incomplete for model representation of this mechanism (McCalley et al., 2014; Schimel and Gulledge, 1998). Although a number of studies have reported the microbial community structure and its potential association with changes in $\mathrm{CH}_{4}$ processes (Schimel, 1995; Wagner et al., 2005), none of this progress has been documented in a mathematical manner suitable for a modeling representation.

Third, a comprehensive data set of all primary $\mathrm{CH}_{4}$ processes within an individual ecosystem would be valuable for model optimization and validation. Although some data sets exist, no study has investigated all primary individual $\mathrm{CH}_{4}$ processes within the same plot over the long term. Given 
the substantial spatial heterogeneity of $\mathrm{CH}_{4}$ processes, this lack of process representation may cause bias in $\mathrm{CH}_{4}$ simulations at a regional scale. It should be noted that landsurface net $\mathrm{CH}_{4}$ flux is a measurable ecosystem-level process, whereas many individual $\mathrm{CH}_{4}$ processes are difficult to accurately measure. Therefore, designing field- or lab-based experiments suitable for measuring these processes is a fundamental need. For example, the anaerobic oxidation of $\mathrm{CH}_{4}$ has been identified as a critical process for some ecosystem types, but no comprehensive data set on it is available for model development or improvement.

Last but not least, high-quality spatial data as driving forces and validation data for $\mathrm{CH}_{4}$ models are critical for model development as well (Melton et al., 2013; Wania et al., 2013). Spatial distribution and dynamics of wetland areas probably are the most important data need for $\mathrm{CH}_{4}$ models (Wania et al., 2013). Spatial distributions of soil temperature, moisture, and texture are fundamental information because they serve as direct or indirect environmental control on $\mathrm{CH}_{4}$ processes. The recently launched Soil Moisture Active Passive (SMAP) satellite could be used as an important data source of soil moisture for driving $\mathrm{CH}_{4}$ models (Entekhabi et al., 2010). It has been identified that soil texture and $\mathrm{pH}$ are important for simulating $\mathrm{CH}_{4}$ processes (Xu et al., 2015). In addition, the atmospheric $\mathrm{CH}_{4}$ concentration data from satellites could be used as an important benchmark for model validation purposes, for example, the Scanning Imaging Absorption spectrometer for Atmospheric ChartographY (SCIAMACHY) (Frankenberg et al., 2005) and the Greenhouse gas Observing SATellite (GOSAT) (Yokota et al., 2009).

\subsection{Data-model integration}

Model development and data collection are two important but historically independent scientific approaches; the integration between model development and data collection is much stronger for advancing science (De Kauwe et al., 2014; Luo et al., 2012; Peng et al., 2011). Although data-model integration is recognized as very important for understanding and predicting $\mathrm{CH}_{4}$ processes and some progress has been made, integrating experiments and models presents multiple challenges, particularly because (1) the methods for integrating data with the models are not well developed for $\mathrm{CH}_{4}$ cycling; (2) the metrics for evaluating data-model integration are not consistent in the scientific community; and (3) regular communication between data scientists and modelers on various aspects of $\mathrm{CH}_{4}$ processes and their model representation is lacking.

Methods for data-model integration have been recently created, for example, Kalman filter (Gao et al., 2011), Bayesian (Ogle and Barber, 2008; Ricciuto et al., 2008; Schleip et al., 2009; Van Oijen et al., 2005), and Markov chain Monte Carlo (Casella and Robert, 2005). However, no studies have evaluated these methods for integrating $\mathrm{CH}_{4}$ data with models. In addition, the metric for evaluating the data-model integration is still not well developed. A very helpful strategy for data-model integration is to solicit timely input from modelers when designing a field experiment. A good example of this is US Department of Energy-sponsored project Next Generation Ecosystem Experiments - Arctic (http://ngee-arctic.ornl.gov), which was planned with inputs from field scientists, data scientists, and modelers. Another successful example is the US DOE-sponsored project, Spruce and Peatland Responses Under Climatic and Environmental Change (SPRUCE) (mnspruce.ornl.gov), in which the experiment design for data-model integration created an opportunity for modeling needs to be adopted by the field scientists. A modeling framework that focuses on model parameterization and validation ability is under development at Oak Ridge National Laboratory; building a model optimization algorithm into an ESM framework will enable more effective parameterization of newly developed $\mathrm{CH}_{4}$ modules within CLM at site, regional, and global scales (Ricciuto et al., personal communication, 16 December 2015).

\section{Concluding remarks}

$\mathrm{CH}_{4}$ dynamics in terrestrial ecosystems have been intensively studied, and model representation of $\mathrm{CH}_{4}$ cycling has evolved as new knowledge becomes available. This is inherently a slow process. Currently, the primary mechanisms for $\mathrm{CH}_{4}$ processes in terrestrial ecosystems are implicitly represented in many, but not all, terrestrial ecosystem models. Development of $\mathrm{CH}_{4}$ models began in the late 1980s, and the pace of growth has been fast since the 1990s. Model development shifted from theoretical analysis in the 1980s and 1990s to being more applied in the 2000s and 2010s, expressed as being more focused on regional $\mathrm{CH}_{4}$ budget quantification and integration with multiple sources of observational data. Although some current $\mathrm{CH}_{4}$ models consider most of the relevant mechanisms, none of them consider all the processes for methanogenesis, methanotrophy, $\mathrm{CH}_{4}$ transport, and their primary environmental controls. Furthermore, evidence demonstrating that incorporating all of these processes would lead to more accurate prediction is needed. Incorporating sophisticated parameter assimilation, uncertainty quantification, equifinality quantification, and metrics of the benefits associated with increased model complexity would also facilitate scientific discovery.

The $\mathrm{CH}_{4}$ models for accurate projection of land-climate feedback in the next few decades should (1) use mechanistic formulations for primary $\mathrm{CH}_{4}$ processes, (2) be embedded in Earth system models for the global evaluation of terrestrialclimate feedback associated with $\mathrm{CH}_{4}$ fluxes, (3) have the capacity to integrate multiple sources of data, which makes the model not only a prediction tool but also an integrative tool, and (4) be developed in association with model benchmarking frameworks. These four characteristics pave the way for 
examining $\mathrm{CH}_{4}$ processes and flux in the context of global change. These improvements for $\mathrm{CH}_{4}$ modeling would be beneficial for ESMs and further simulation of climate-carbon cycle feedbacks.

Acknowledgements. The authors are grateful for financial and facility support from San Diego State University and the University of Texas at El Paso. The authors are grateful to Yiqi Luo at the University of Oklahoma for his comments on early versions of the manuscript. We are grateful to Jens-Arne Subke and five anonymous reviewers for their constructive comments that significantly improved this paper. This review is part of the $\mathrm{CH}_{4}$ modeling tasks within the NGEE-Arctic and SPRUCE projects sponsored by the US Department of Energy Office of Science. Contributions by Fengming Yuan, Paul J. Hanson, Peter E. Thornton, Stan D. Wullschleger, and David E. Graham are supported by the US Department of Energy, Office of Science, Office of Biological and Environmental Research. Oak Ridge National Laboratory is managed by UT-Battelle, LLC, for the US Department of Energy under contract DE-AC05-00OR22725. Contributions by William J. Riley are supported by the US Department of Energy under contract no. DE-AC02-05CH11231. Changchun Song is supported by the National Natural Science Foundation of China (41125001), and Hanqin Tian is supported by the NASA Carbon Monitoring System Program (NNX14AO73G) and the NASA Interdisciplinary Science Program (NNX14AF93G).

Edited by: J.-A. Subke

\section{References}

Anisimov, O. A.: Potential feedback of thawing permafrost to the global climate system through methane emission, Environ. Res. Lett., 2, 045016, doi:10.1088/1748-9326/2/4/045016, 2007.

Arah, J. R. M. and Kirk, G. J. D.: Modeling rice plant-mediated methane emission, Nutr. Cycl. Agroecosys., 58, 221-230, 2000.

Arah, J. R. M. and Stephen, K. D.: A model of the processes leading to methane emission from peatland, Atmos. Environ., 32, 32573264, 1998.

Aronson, E. and Helliker, B.: Methane flux in non-wetland soils in response to nitrogen addition: a meta-analysis, Ecology, 91, 3242-3251, 2010.

Askaer, L., Elberling, B., Friborg, T., Jørgensen, C. J., and Hansen, B. U.: Plant-mediated $\mathrm{CH}_{4}$ transport and $\mathrm{C}$ gas dynamics quantified in-situ in a Phalaris arundinacea-dominant wetland, Plant Soil, 343, 287-301, 2011.

Aulakh, M. S., Wassmann, R., Rennenberg, H., and Fink, S.: Pattern and amount of aerenchyma relate to variable methane transport capacity of different rice cultivars, Plant Biol., 2, 182-194, 2000.

Banger, K., Tian, H., and Lu, C.: Do nitrogen fertilizers stimulate or inhibit methane emissions from rice fields?, Glob. Change Biol., 18, 3259-3267, 2012.

Barber, T. R., Burke, R. A., and Sackett, W. M.: Diffusive flux of methane from warm wetlands, Global Biogeochem. Cy., 2, 411425, 1988.

Barlett, K. B. and Harriss, R. C.: Review and assessment of methane emissions from wetlands, Chemosphere, 26, 261-320, 1993.
Becker, T., Kutzbach, L., Forbrich, I., Schneider, J., Jager, D., Thees, B., and Wilmking, M.: Do we miss the hot spots? The use of very high resolution aerial photographs to quantify carbon fluxes in peatlands, Biogeosciences, 5, 1387-1393, doi:10.5194/bg-5-1387-2008, 2008.

Beckett, P. M., Armstrong, W., and Armstrong, J.: Mathematical modelling of methane transport by Phragmites: the potential for diffusion within the roots and rhizosphere, Aquat. Bot., 69, 293312, 2001.

Beerling, D. J., Gardiner, T., Leggett, G., Mcleod, A., and Quick, W. P.: Missing methane emissions from leaves of terrestrial plants, Glob. Change Biol., 14, 1821-1826, 2008.

Bellisario, L., Bubier, J., Moore, T., and Chanton, J.: Controls on $\mathrm{CH}_{4}$ emissions from a northern peatland, Global Biogeochem. Cy., 13, 81-91, 1999.

Bhadra, A., Mukhopadhyay, S. N., and Ghose, T. K.: A kinetic model for methanogenesis of acetic acid in a multireactor system, Biotechnol. Bioeng., 26, 257-264, 1984.

Blazewicz, S. J., Petersen, D. G., Waldrop, M. P., and Firestone, M. K.: Anaerobic oxidation of methane in tropical and boreal soils: Ecological significance in terrestrial methane cycling, J. Geophys. Res.-Biogeo., 117, G02033, doi:10.1029/2011JG001864, 2012.

Blodau, C.: Carbon cycling in peatlands-A review of processes and controls, Environ. Rev., 10, 111-134, 2002.

Bohn, T. J. and Lettenmaier, D. P.: Systematic biases in largescale estimates of wetland methane emissions arising from water table formulations, Geophys. Res. Lett., 37, L22401, doi:10.1029/2010GL045450, 2010.

Bohn, T. J., Lettenmaier, D. P., Sathulur, K., Bowling, L. C., Podest, E., McDonald, K. C., and Friborg, T.: Methane emissions from western Siberian wetlands: heterogeneity and sensitivity to climate change, Environ. Res. Lett., 2, 045015, doi:10.1088/17489326/2/4/045015, 2007.

Bohn, T. J., Melton, J. R., Ito, A., Kleinen, T., Spahni, R., Stocker, B. D., Zhang, B., Zhu, X., Schroeder, R., Glagolev, M. V., Maksyutov, S., Brovkin, V., Chen, G., Denisov, S. N., Eliseev, A. V., Gallego-Sala, A., McDonald, K. C., Rawlins, M. A., Riley, W. J., Subin, Z. M., Tian, H., Zhuang, Q., and Kaplan, J. O.: WETCHIMP-WSL: intercomparison of wetland methane emissions models over West Siberia, Biogeosciences, 12, 3321-3349, doi:10.5194/bg-12-3321-2015, 2015.

Bridgham, S. D., Cadillo-Quiroz, H., Keller, J. K., and Zhuang, Q.: Methane emissions from wetlands: biogeochemical, microbial, and modeling perspective from local to global scales, Glob. Change Biol., 19, 1325-1346, 2013.

Butterbach-Bahl, K., Papen, H., and Rennenberg, H.: Impact of gas transport through rice cultivars on methane emission from rice paddy fields, Plant Cell Environ., 20, 1175-1183, 1997.

Cai, Z.: Greenhouse gas budget for terrestrial ecosystems in China, Science China - Earth Sciences, 55, 173-182, 2012.

Caldwell, S. L., Laidler, J. R., Brewer, E. A., Eberly, J. O., Sandborgh, S. C., and Colwell, F. S.: Anaerobic oxidation of methane: mechanisms, bioenergetics, and ecology of associated microorganisms, Environ. Sci. Technol., 42, 6791-6799, 2008.

Cao, M. K., Dent, J. B., and Heal, O. W.: Modeling methane emissions from rice paddies, Global Biogeochem. Cy., 9, 183-195, 1995. 
Cao, M. K., Gregson, K., and Marshall, S.: Global methane emission from wetlands and its sensitivity to climate change, Atmos. Environ., 32, 3293-3299, 1998.

Casella, G. and Robert, C. (Eds.): Monte Carlo statistical methods, Springer, New York, 2005.

Chanton, J. P.: The effect of gas transport on the isotope signature of methane in wetlands, Org. Geochem., 36, 753-768, 2005.

Chanton, J. P., Martens, C. S., and Kelley, C. A.: Gas transport from methane-saturated, tidal freshwater and wetland sediments, Limnol. Oceanogr, 34, 807-819, 1989.

Chen, H., Zhu, Q., Peng, C., Wu, N., Wang, Y., Fang, X., Jiang, H., Xiang, W., Chang, J., Deng, X., and Yu, G.: Methane emissions from rice paddies natural wetlands, and lakes in China: synthesis and new estimate, Glob. Change Biol., 19, 19-32, 2012.

Christensen, T. and Cox, P.: Response of methane emission from Arctic tundra to climatic change: results from a model simulation, Tellus B, 47, 301-309, 1995.

Christensen, T. R., Prentice, I. C., Kaplan, J. O., Haxeltine, A., and Sitch, S.: Methane flux from northern wetlands and tundra an ecosystem source modeling approach, Tellus, 48B, 652-661, 1996.

Colmer, T.: Long distance transport of gases in plants: a perspective on internal aeration and radial oxygen loss from roots, Plant Cell Environ., 26, 17-36, 2003.

Conrad, R.: Contribution of hydrogen to methane production and control of hydrogen concentration in methanogenic soils and sediments, FEMS Microbiol. Ecol., 28, 193-202, 1999.

Conrad, R.: Control of methane production in terrestrial ecosystems, in: Exchange of trace gases between terrestrial ecosystems and the atmosphere, edited by: Andrease, M. O. and Schimel, D. S., Springer, New York, 39-58, 1989.

Conrad, R.: Soil microbial processes involved in production and consumption of atmospheric trace gases, in: Advances in microbial ecology, Springer, 207-250, 1995.

Conrad, R.: Soil microorganisms as controllers of atmospheric trace gases $\left(\mathrm{H}_{2}, \mathrm{CO}, \mathrm{CH}_{4}, \mathrm{OCS}, \mathrm{N}_{2} \mathrm{O}\right.$, and $\left.\mathrm{NO}\right)$, Microbiol. Rev., 60, 609-640, 1996.

Conrad, R.: Quantification of methanogenic pathways using stable carbon isotopic signatures: a review and a proposal, Org. Geochem., 36, 739-752, 2005.

Conrad, R.: The global methane cycle: recent advances in understanding the microbial processes involved, Environ. Microbiol. Reports, 1, 285-292, 2009.

Conrad, R. and Claus, P.: Contribution of methanol to the production of methane and its ${ }^{13} \mathrm{C}$-isotopic signature in anoxic rice field soil, Biogeochemistry, 73, 381-393, 2005.

Conrad, R. and Klose, M.: How specific is the inhibition by methyl fluoride of acetoclastic methanogenesis in anoxic rice field soil?, FEMS Microbiol. Ecol., 30, 47-56, 1999.

Cresto Aleina, F., Runkle, B. R. K., Kleinen, T., Kutzbach, L., Schneider, J., and Brovkin, V.: Modeling micro-topographic controls on boreal peatland hydrology and methane fluxes, Biogeosciences, 12, 5689-5704, doi:10.5194/bg-12-5689-2015, 2015.

Curry, C. L.: Modeling the soil consumption of atmospheric methane at the global scale, Global Biogeochem. Cy., 21, GB4012, doi:10.1029/2006GB002818, 2007.

Curry, C. L.: The consumption of atmospheric methane by soil in a simulated future climate, Biogeosciences, 6, 2355-2367, doi:10.5194/bg-6-2355-2009, 2009.
De Haas, Y., Windig, J., Calus, M., Dijkstra, J., De Haan, M., Bannink, A., and Veerkamp, R.: Genetic parameters for predicted methane production and potential for reducing enteric emissions through genomic selection, J. Dairy Sci., 94, 6122-6134, 2011.

De Kauwe, M. G., Medlyn, B. E., Zaehle, S., Walker, A. P., Dietze, M. C., Wang, Y. P., Luo, Y., Jain, A. K., El Masri, B., and Hickler, T.: Where does the carbon go? A model-data intercomparison of vegetation carbon allocation and turnover processes at two temeperate forest free air $\mathrm{CO}_{2}$, enrichment sites, New Phytol., 203, 883-899, 2014.

Del Grosso, S. J., Ojima, D., Parton, W. J., Mosier, A., Peterson, G., and Schimel, D.: Simulated effects of dryland cropping intensification on soil organic matter and greenhouse gas exchanges using the DAYCENT ecosystem model, Environ. Pollut., 116, S75-S83, 2002.

Del Grosso, S. J., Ojima, D. S., Parton, W. J., Stehfest, E., Heistemann, M., DeAngelo, B. J., and Rose, S.: Global scale DAYCENT model analysis of greenhouse gas emissions and mitigation strategies for cropped soils, Global Planet. Change, 67, 44$50,2009$.

Del Grosso, S. J., Parton, W. J., Mosier, A. R., Ojima, D. S., Potter, C. S., Borken, W., Brumme, R., Butterbach-Bahl, K., Crill, P. M., Dobbie, K. E., and Smith, K. A.: General $\mathrm{CH}_{4}$ oxidation model and comparisons of $\mathrm{CH}_{4}$ oxidation in natural and managed systems, Global Biogeochem. Cy., 14, 999-1019, 2000.

DeLong, E. F., Harwood, C. S., Chisholm, P. W., Karl, D. M., Moran, M. A., Schmidt, T. M., Tiedje, J. M., Treseder, K. K., and Worden, A. Z.: Incorporating microbial processes into climate models, The American Academy of Microbiology, Washington DC, 2011.

De Visscher, A. and Van Cleemput, O.: Simulation model for gas diffusion and methane oxidation in landfill cover soils, Waste Manage., 23, 581-591, 2003.

Ding, A. and Wang, M.: Model for methane emission from rice paddies and its application in southern China, Adv. Atmos. Sci., 13, 159-168, 1996.

Dueck, T. A., De Visser, R., Poorter, H., Persijn, S., Gorissen, A., De Visser, W., Schapendonk, A., Verhagen, J., Snel, J., and Harren, F. J.: No evidence for substantial aerobic methane emission by terrestrial plants: a 13C labelling approach, New Phytol., 175, 29-35, 2007.

Eliseev, A. V., Mokhov, I. I., Arzhanov, M. M., Demchenko, P. F., and Denisov, S. N.: Interaction of the methane cycle and processes in wetland ecosystems in a climate model of intermediate complexity, Atmos. Ocean. Phys., 44, 139-152, 2008.

Elliott, S., Maltrud, M., Reagan, M., Moridis, G., and Cameron Smith, P.: Marine methane cycle simulations for the period of early global warming, J. Geophys. Res.-Biogeo., 116, G01010, doi:10.1029/2010JG001300, 2011.

Entekhabi, D., Njoku, E. G., O’Neill, P. E., Kellogg, K. H., Crow, W. T., Edelstein, W. N., Entin, J. K., Goodman, S. D., Jackson, T. J., and Johnson, J.: The soil moisture active passive (SMAP) mission, Proceedings of the IEEE, 98, 704-716, 2010.

Evans, M. R., Grimm, V., Johst, K., Knuuttila, T., de Langhe, R., Lessells, C. M., Merz, M., O’Malley, M. A., Orzack, S. H., and Weisberg, M.: Do simple models lead to generality in ecology?, Trends Ecol. Evol., 28, 578-583, 2013.

Falz, K. Z., Holliger, C., Grosskopf, R., Liesack, W., Nozhevnikova, A., Müller, B., Wehrli, B., and Hahn, D.: Vertical distribution 
of methanogens in the anoxic sediment of Rotsee (Switzerland), Appl. Environ. Microb., 65, 2402-2408, 1999.

Fan, Z., David McGuire, A., Turetsky, M. R., Harden, J. W., Michael Waddington, J., and Kane, E. S.: The response of soil organic carbon of a rich fen peatland in interior Alaska to projected climate change, Glob. Change Biol., 19, 604-620, 2013.

Forster, P., Ramaswamy, V., Artaxo, P., Berntsen, T., Betts, R., Fahey, D. W., Haywood, J., Lean, J., Lowe, D. C., Myhre, G., Nganga, J., Prinn, N. R., Raga, G., Schulz, M., and Dorland, R. V.: Changes in atmospheric constituents and in radiative forcing, in: Climate change 2007: The physical science basis. Contribution of working group I to the fourth assessment report of the intergovernmental panel on climate change, edited by: Solomon, S., Qin, D., Manning, M., and Chen, Z., Cambridge University Press, Cambridge, United Kingdom and New York, USA, 133216, 2007.

Frankenberg, C., Meirink, J. F., Van Weele, M., Platt, U., and Wagner, T.: Assessing methane emissions from global space-borne observations, Science, 308, 1010-1014, 2005.

Frenzel, P. and Karofeld, E.: $\mathrm{CH}_{4}$ emission from a hollow-ridge complex in a raised bog: the role of $\mathrm{CH}_{4}$ production and oxidation, Biogeochemistry, 51, 91-112, 2000.

Frenzel, P. and Rudolph, J.: Methane emission from a wetland plant: the role of $\mathrm{CH}_{4}$ oxidation in Eriophorum, Plant Soil, 202, 27-32, 1998.

Gao, C., Wang, H., Weng, E., Lakshmivarahan, S., Zhang, Y., and Luo, Y.: Assimilation of multiple data sets with the ensemble Kalman filter to improve forecasts of forest carbon dynamics, Ecol. Appl., 21, 1461-1473, 2011.

Gao, X., Schlosser, C. A., Sokolov, A., Anthony, K. W., Zhuang, Q., and Kicklighter, D.: Permafrost degradation and methane: low risk of biogeochemical climate-warming feedback, Environ. Res. Lett., 8, 035014, doi:10.1088/1748-9326/8/3/035014, 2013.

Gauthier, M., Bradley, R. L., and Šimek, M.: More evidence that anaerobic oxidation of methane is prevalent in soils: Is it time to upgrade our biogeochemical models?, Soil Biol. Biochem., 80, $167-174,2015$

Gedney, N., Cox, P., and Huntingford, C.: Climate feedback from wetland methane emissions, Geophys. Res. Lett., 31, L20503, doi:10.1029/2004GL020919, 2004.

Gerard, G. and Chanton, J.: Quantification of methane oxidation in the rhizosphere of emergent aquatic macrophytes: defining upper limits, Biogeochemistry, 23, 79-97, 1993.

Gong, J., Kellomaki, S., Wang, K., Zhang, C., Shurpali, N., and Martikainen, P. J.: Modeling $\mathrm{CO}_{2}$ and $\mathrm{CH}_{4}$ flux changes in pristine peatlands of Finland under changing climate conditions, Ecol. Model., 263, 64-80, 2013.

Grant, R. and Roulet, N.: Methane efflux from boreal wetlands: Theory and testing of the ecosystem model Ecosys with chamber and tower flux measurements, Global Biogeochem. Cy., 16, 2-1-2-16, 2002.

Grant, R., Juma, N., and McGill, W.: Simulation of carbon and nitrogen transformations in soil: mineralization, Soil Biol. Biochem., 25, 1317-1329, 1993.

Grant, R. F.: Simulation of methanogenesis in the mathematical model Ecosys, Soil Biol. Biochem., 30, 883-896, 1998.

Grant, R. F.: A review of the Canadian ecosystem model ecosys, in: Modeling Carbon and Nitrogen Dynamics for Soil Management, edited by: Shaffer, M. J., Ma, L., and Hansen, S., CRC Press, New York, 173-264, 2001.

Gulledge, J. and Schimel, J. P.: Low-concentration kinetics of atmospheric $\mathrm{CH}_{4}$ oxidation in soil and mechanism of $\mathrm{NH}_{4}^{+}$inhibition, Appl. Environ. Microb., 64, 4291-4298, 1998a.

Gulledge, J. and Schimel, J. P.: Moisture control over atmospheric $\mathrm{CH}_{4}$ consumption and $\mathrm{CO}_{2}$ production in diverse Alaskan soils, Soil Biol. Biochem., 30, 1127-1132, 1998b.

Hakemian, A. S. and Rosenzweig, A. C.: The biochemistry of methane oxidation, Annu. Rev. Biochem., 76, 223-241, 2007.

Hanson, R. S. and Hanson, T. E.: Methanotrophic bacteria, Microbiol. Mol. Biol. R., 60, 60, 439-471, 1996.

Heilman, M. A. and Carlton, R. G.: Methane oxidation associated with submersed vascular macrophytes and its impact on plant diffusive methane flux, Biogeochemistry, 52, 207-224, 2001.

Higgins, I. J., Best, D. J., Hammond, R. C., and Scott, D.: Methaneoxidizing microorganisms, Microbiol. Rev., 45, 556-590, 1981.

Hodson, E. L., Poulter, B., Zimmermann, N. E., Prigent, C., and Kaplan, J. O.: The El Nino-Southern Oscillation and wetland methane interannual variability, Geophys. Res. Lett., 38, L08810, doi:10.1029/2011GL046861, 2011.

Holgerson, M. A. and Raymond, P. A.: Large contribution to inland water $\mathrm{CO}_{2}$ and $\mathrm{CH}_{4}$ emissions from very small ponds, Nat. Geosci., 9, 222-226, 2016.

Hopcroft, P. O., Valdes, P. J., and Beerling, D. J.: Simulating idealized Dansgaard-Oeschger events and their potential impacts on the global methane cycle, Quarternary Sci. Rev., 30, 3258-3268, 2011.

Hosono, T. and Nouchi, I.: The dependence of methane transport in rice plants on the root zone temperature, Plant Soil, 191, 233 240, 1997.

Huang, Y., Sass, R. L., and Fisher, F. M.: Model estimates of methane emission from irrigated rice cultivation of China, Glob. Change Biol., 4, 809-821, doi:10.1046/j.13652486.1998.00175.x, 1998a.

Huang, Y., Sass, R. L., and Fisher, F. M.: A semi-empirical model of methane emission from flooded rice paddy soils, Glob. Change Biol., 4, 247-268, 1998b.

Huang, Y., Zhang, W., Zheng, X., Li, J., and Yu, Y.: Modeling methane emission from rice paddies with various agricultural practices, J. Geophys. Res., 109, D08113, doi:10.1029/2003JD004401, 2004.

Inatomi, M., Ito, A., Ishijima, K., and Murayama, S.: Greenhouse gas budget of a cool-temperate deciduous broad-leaved forest in Japan estimated using a process-based model, Ecosystems, 13, 472-483, 2010.

IPCC: Summary for policymakers, Cambridge, United Kingdom and New York, NY, USA, 2013.

Ito, A. and Inatomi, M.: Use of a process-based model for assessing the methane budgets of global terrestrial ecosystems and evaluation of uncertainty, Biogeosciences, 9, 759-773, doi:10.5194/bg9-759-2012, 2012

Karl, D. M., Beversdorf, L., Björkman, K. M., Church, M. J., Martinez, A., and Delong, E. F.: Aerobic production of methane in the sea, Nat. Geosci., 1, 473-478, 2008.

Keppler, F., Hamilton, J. T. G., Brass, M., and Rockmann, T.: Methane emissions from terrestrial plants under aerobic conditions, Nature, 439, 187-191, 2006. 
Kettunen, A.: Connecting methane fluxes to vegetation cover and water table fluctuations at microsite level: a modeling study, Global Biogeochem. Cy., 17, 1051, doi:10.1029/2002GB001958, 2003.

King, G. M.: In Situ Analyses of Methane Oxidation Associated with the Roots and Rhizomes of a Bur Reed, Sparganium eurycarpum, in a Maine Wetland, Appl. Environ. Microb., 62, 4548-4555, 1996.

Kotsyurbenko, O. R., Chin, K. J., Glagolev, M. V., Stubner, S., Simankova, M. V., Nozhevnikova, A. N., and Conrad, R.: Acetoclastic and hydrogenotrophic methane production and methanogenic populations in an acidic West Siberian peat bog, Environ. Microbiol., 6, 1159-1173, 2004.

Koven, C. D., Ringeval, B., Friedlingstein, P., Ciais, P., Cadule, P., Khvorostyanov, D., Krinner, G., and Tarnocai, C.: Permafrost carbon-climate feedbacks accelerate global warming, P. Natl. Acad. Sci. USA, 108, 14769-14774, 2011.

Koven, C. D., Riley, W. J., Subin, Z. M., Tang, J. Y., Torn, M. S., Collins, W. D., Bonan, G. B., Lawrence, D. M., and Swenson, S. C.: The effect of vertically resolved soil biogeochemistry and alternate soil $\mathrm{C}$ and $\mathrm{N}$ models on $\mathrm{C}$ dynamics of CLM4, Biogeosciences, 10, 7109-7131, doi:10.5194/bg-10-7109-2013, 2013.

Krüger, M., Frenzel, P., and Conrad, R.: Microbial processes influencing methane emission from rice fields, Glob. Change Biol., 7, 49-63, 2001.

Krumholz, L. R., Hollenback, J. L., Roskes, S. J., and Ringelberg, D. B.: Methanogenesis and methanotrophy within a Sphagnum peatland, FEMS Microbiol. Ecol., 18, 215-224, 1995.

Lai, D. Y. F.: Methane dynamics in Northern Peatlands: A Review, Pedosphere, 19, 409-421, 2009.

Larsen, P. E., Gibbons, S. M., and Gilbert, J. A.: Modeling microbial community structure and functional diversity across time and space, FEMS Microbiol. Lett., 332, 91-98, 2012.

Lenhart, K., Bunge, M., Ratering, S., New, T. R., Schuttmann, I., Greule, M., Kammann, C., Schnell, S., Muller, C., Zorn, H., and Keppler, F.: Evidence for methane production by saprotrophic fungi, Nat. Commun., 3, 1046, doi:10.1038/ncomms2049, 2012.

Li, C.: Modeling trace gas emissions from agricultural ecosystems, Nutr. Cycl. Agroecosys., 58, 259-276, 2000.

Li, C., Frolking, S., Xiao, X., Moore III, B., Boles, S., Qiu, J., Huang, Y., Salas, W., and Sass, R.: Modeling impacts of farming management alternatives on $\mathrm{CO}_{2}, \mathrm{CH}_{4}$, and $\mathrm{N}_{2} \mathrm{O}$ emissions: a case study for water management of rice agriculture of China, Global Biogeochem. Cy., 19, GB3010, doi:10.1029/2004GB002341, 2005.

Li, T., Huang, Y., Zhang, W., and Yu, Y.-Q.: Methane emissions associated with the conversion of marshland to cropland and climate change on the Sanjiang Plain of northeast China from 1950 to 2100, Biogeosciences, 9, 5199-5215, doi:10.5194/bg-9-51992012, 2012.

Liu, L. and Greaver, T.: A review of nitrogen enrichment effects on three biogenic GHGs: the $\mathrm{CO}_{2}$ sink may be largely offset by stimulated $\mathrm{N}_{2} \mathrm{O}$ and $\mathrm{CH}_{4}$ emission, Ecol. Lett., 12, 1103-1117, 2009.

Lovley, D. P. and Klug, M. J.: Model for distribution of sulfate reduction and methanogenesis in freshwater sediments, Geochim. Cosmochim. Ac., 50, 11-18, 1986.

Luo, Y. Q., Randerson, J. T., Abramowitz, G., Bacour, C., Blyth, E., Carvalhais, N., Ciais, P., Dalmonech, D., Fisher, J. B., Fisher,
R., Friedlingstein, P., Hibbard, K., Hoffman, F., Huntzinger, D., Jones, C. D., Koven, C., Lawrence, D., Li, D. J., Mahecha, M., Niu, S. L., Norby, R., Piao, S. L., Qi, X., Peylin, P., Prentice, I. C., Riley, W., Reichstein, M., Schwalm, C., Wang, Y. P., Xia, J. Y., Zaehle, S., and Zhou, X. H.: A framework for benchmarking land models, Biogeosciences, 9, 3857-3874, doi:10.5194/bg-93857-2012, 2012.

Martens, C. S., Albert, D. B., and Alperin, M. J.: Biogeochemical processes controlling methane in gassy coastal sediments - Part 1, A model coupling organic matter flux to gas production, oxidation and transport, Cont. Shelf Res., 18, 1741-1770, 1998.

Martinson, G. O., Werner, F. A., Scherber, C., Conrad, R., Corre, M. D., Flessa, H., Wolf, K., Klose, M., Gradstein, S. R., and Veldkamp, E.: Methane emissions from tank bromeliads in neotropical forests, Nat. Geosci., 3, 766-769, 2010.

Massman, W., Sommerfeld, R., Mosier, A., Zeller, K., Hehn, T., and Rochelle, S.: A model investigation of turbulence driven pressure pumping effects on the rate of diffusion of $\mathrm{CO}_{2}, \mathrm{~N}_{2} \mathrm{O}$, and $\mathrm{CH}_{4}$ through layered snowpacks, J. Geophys. Res.-Atmos., 102, 18851-18863, 1997.

Mastepanov, M., Sigsgaard, C., Dlugokencky, E. J., Houweling, S., Strom, L., Tamstorf, M. P., and Christensen, T. R.: Large tundra methane burst during onset of freezing, Nature, 456, 628-630, 2008.

Matthews, E. and Fung, I.: Methane emissions from natural wetlands: global distribution, area and environmental characteristics of sources, Global Biogeochem. Cy., 1, 61-86, 1987.

Matthews, R. B., Wassmann, R., and Arah, J. R. M.: Using a crop/soil simulation model and GIS techniques to assess methane emissions from rice fields in Asia, I. model development, Nutr. Cycl. Agroecosys., 58, 141-159, 2000.

Mau, S., Blees, J., Helmke, E., Niemann, H., and Damm, E.: Vertical distribution of methane oxidation and methanotrophic response to elevated methane concentrations in stratified waters of the Arctic fjord Storfjorden (Svalbard, Norway), Biogeosciences, 10, 6267-6278, doi:10.5194/bg-10-6267-2013, 2013.

McCalley, C. K., Woodcroft, B. J., Hodgkins, S. B., Wehr, R. A., Kim, E.-H., Mondav, R., Crill, P. M., Chanton, J. P., Rich, V. I., Tyson, G. W., and Saleska, S. R.: Methane dynamics regulated by microbial community response to permafrost thaw, Nature, 514, 478-481, 2014.

Melloh, R. A. and Crill, P. M.: Winter methane dynamics in a temperate peatland, Global Biogeochem. Cy., 10, 247-254, 1996.

Melton, J. R., Wania, R., Hodson, E. L., Poulter, B., Ringeval, B., Spahni, R., Bohn, T., Avis, C. A., Beerling, D. J., Chen, G., Eliseev, A. V., Denisov, S. N., Hopcroft, P. O., Lettenmaier, D. P., Riley, W. J., Singarayer, J. S., Subin, Z. M., Tian, H., Zürcher, S., Brovkin, V., van Bodegom, P. M., Kleinen, T., Yu, Z. C., and Kaplan, J. O.: Present state of global wetland extent and wetland methane modelling: conclusions from a model intercomparison project (WETCHIMP), Biogeosciences, 10, 753788, doi:10.5194/bg-10-753-2013, 2013.

Meng, L., Hess, P. G. M., Mahowald, N. M., Yavitt, J. B., Riley, W. J., Subin, Z. M., Lawrence, D. M., Swenson, S. C., Jauhiainen, J., and Fuka, D. R.: Sensitivity of wetland methane emissions to model assumptions: application and model testing against site observations, Biogeosciences, 9, 2793-2819, doi:10.5194/bg-92793-2012, 2012. 
Mer, J. L. and Roger, P.: Production, oxidation, emission and consumption of methane by soils: a review, Eur. J. Soil Biol., 37, 25-50, 2001.

Miller, K. E., Lai, C.-T., Friedman, E. S., Angenent, L. T., and Lipson, D. A.: Methane suppression by iron and humic acids in soils of the Arctic Coastal Plain, Soil Biol. Biochem., 83, 176-183, 2015.

Mokhov, I. I., Eliseev, A. V., and Denisov, S. N.: Model diagnostics of variations in methane emissions by wetlands in the second half of the 20th century based on reanalysis data, Dokl. Earth Sci., 417, 1293-1297, 2007.

Monechi, S., Coccioni, R., and Rampino, M. R.: Large ecosystem perturbations: causes and consequences, Geological Society of America, Boulder, Colo., 2007.

Morrissey, L. and Livingston, G.: Methane emissions from Alaska arctic tundra: An assessment of local spatial variability, J. Geophys. Res.-Atmos., 97, 16661-16670, 1992.

Mosier, A., Delgado, J., Cochran, V., Valentine, D., and Parton, W.: Impact of agriculture on soil consumption of atmospheric $\mathrm{CH}_{4}$ and a comparison of $\mathrm{CH}_{4}$ and $\mathrm{N}_{2} \mathrm{O}$ flux in subarctic, temperate and tropical grasslands, Nutr. Cycl. Agroecosys., 49, 71-83, 1997.

Murase, J. and Kimura, M.: Methane production and its fate in paddy fields: IX. Methane flux distribution and decomposition of methane in the subsoil during the growth period of rice plants, Soil Sci. Plant Nutr., 42, 187-190, 1996.

Nauta, A. L., Heijmans, M. M., Blok, D., Limpens, J., Elberling, B., Gallagher, A., Li, B., Petrov, R. E., Maximov, T. C., and van Huissteden, J.: Permafrost collapse after shrub removal shifts tundra ecosystem to a methane source, Nature Climate Change, 5, 67-70, 2015.

Nazaries, L., Murrell, J. C., Millard, P., Baggs, L., and Singh, B. K.: Methane, microbes and models: fundamental understanding of the soil methane cycle for future predictions, Environ. Microbiol., 15, 2395-417, doi:10.1111/1462-2920.12149, 2013.

Nouchi, I., Mariko, S., and Aoki, K.: Mechanism of methane transport from the rhizosphere to the atmosphere through rice plants, Plant Physiol. 94, 59-66, 1990.

Nouchi, I., Hosono, T., Aoki, K., and Minami, K.: Seasonal variation in methane flux from rice paddies associated with methane concentration in soil water, rice biomass and temperature, and its modelling, Plant Soil, 161, 195-208, 1994.

Ogle, K. and Barber, J. J.: Bayesian data-model integration in plant physiological and ecosystem ecology, in: Progress in botany, Springer Verlag, Berlin, Heidelberg, 281-311, 2008.

Pareek, S., Matsui, S., Kim, S. K., and Shimizu, Y.: Mathematical modeling and simulation of methane gas production in simulated landfill column reactors under sulfidogenic and methanogenic environments, Water Sci. Technol., 39, 235-242, 1999.

Peng, C., Guiot, J., Wu, H., Jiang, H., and Luo, Y.: Integrating models with data in ecology and palaeoecology: advances towards a model-data fusion approach, Ecol. Lett., 14, 522-536, 2011.

Philippot, L., Andersson, S. G., Battin, T. J., Prosser, J. I., Schimel, J. P., Whitman, W. B., and Hallin, S.: The ecological coherence of high bacterial taxonomic ranks, Nat. Rev. Microbiol., 8, 523529, 2010.

Potter, C. S.: An ecosystem simulation model for methane production and emission from wetlands, Global Biogeochem. Cy., 11, 495-506, 1997.
Potter, C. S., Davidson, E. A., and Verchot, L. V.: Estimation of global biogeochemical controls and seasonality in soil methane consumption, Chemosphere, 32, 2219-2246, 1996.

Ren, W., Tian, H., Xu, X., Liu, M., Lu, C., Chen, G., Melillo, J., Reilly, J., and Liu, J.: Spatial and temporal patterns of $\mathrm{CO}_{2}$ and $\mathrm{CH}_{4}$ fluxes in China's croplands in response to multifactor environmental changes, Tellus B, 63, 222-240, 2011.

Ricciuto, D. M., Davis, K. J., and Keller, K.: A bayesian calibration of a simple carbon cycle model: the role of observations in estimating and reducing uncertainty, Global Biogeochem. Cy., 22, GB2030, doi:2010.1029/2006GB002908, 2008.

Ridgwell, A. J., Marshall, S. J., and Gregson, K.: Consumption of atmospheric methane by soils: a process-based model, Global Biogeochem. Cy., 13, 59-70, 1999.

Riley, W. J., Subin, Z. M., Lawrence, D. M., Swenson, S. C., Torn, M. S., Meng, L., Mahowald, N. M., and Hess, P.: Barriers to predicting changes in global terrestrial methane fluxes: analyses using CLM4Me, a methane biogeochemistry model integrated in CESM, Biogeosciences, 8, 1925-1953, doi:10.5194/bg-8-19252011, 2011.

Ringeval, B., de Noblet-Ducoudre, N., Ciais, P., Bousquet, P., Prigent, C., Para, F., and Rossow, W. B.: An attempt to quantify the impact of changes in wetland extent on methane emissions on the seasonal and interannual time scales, Global Biogeochem. Cy., 24, GB2003, doi:10.1029/2008GB003354, 2010.

Ringeval, B., Friedlingstein, P., Koven, C., Ciais, P., de NobletDucoudré, N., Decharme, B., and Cadule, P.: Climate- $\mathrm{CH}_{4}$ feedback from wetlands and its interaction with the climate$\mathrm{CO}_{2}$ feedback, Biogeosciences, 8, 2137-2157, doi:10.5194/bg8-2137-2011, 2011.

Rodhe, H.: A comparison of the contribution of various gases to the greenhouse effect, Science, 248, 1217-1219, 1990.

Schimel, J.: Ecosystem consequences of microbial diversity and community structure, in: Arctic and alpine biodiversity: patterns, causes and ecosystem consequences, Springer, Springer-Verlag, Berlin, Heidelberg, 239-254, 1995.

Schimel, J. P. and Gulledge, J.: Microbial community structure and global trace gases, Glob. Change Biol., 4, 745-758, 1998.

Schleip, C., Rais, A., and Menzel, A.: Bayesian analysis of temperature sensitivity of plant phenology in Germany, Agr. Forest Meteorol., 149, 1699-1708, 2009.

Schütz, H., Seiler, W., and Conrad, R.: Processes involved in formation and emission of methane in rice paddies, Biogeochemistry, 7, 33-53, 1989.

Segers, R.: Methane production and methane consumption: a review of processes underlying wetland methane fluxes, Biogeochemistry, 41, 23-51, 1998.

Segers, R. and Kengen, S. W. M.: Methane production as a function of anaerobic carbon mineralization: a process model, Soil Biol. Biochem., 30, 1107-1117, 1998.

Segers, R. and Leffelaar, P. A.: Modeling methane fluxes in wetlands with gas-transporting plants 1 , single-root scale, J. Geophys. Res., 106, 3511-3528, 2001 a.

Segers, R. and Leffelaar, P. A.: Modeling methane fluxes in wetlands with gas-transporting plants 3, plot scale, J. Geophys. Res., 106, 3541-3558, $2001 b$.

Segers, R., Rappoldt, C., and Leffelaar, P. A.: Modeling methane fluxes in wetlands with gas-transporting plants 2, soil layer scale, J. Geophys. Res., 106, 3529-3540, 2001. 
Shoemaker, J. K., Keenan, T. F., Hollinger, D. Y., and Richardson, A. D.: Forest ecosystem changes from annual methane source to sink depending on late summer water balance, Geophys. Res. Lett., 41, 673-679, 2014.

Smemo, K. A. and Yavitt, J. B.: Anaerobic oxidation of methane: an underappreciated aspect of methane cycling in peatland ecosystems?, Biogeosciences, 8, 779-793, doi:10.5194/bg-8-779-2011, 2011.

Söhngen, N.: Über Bakterien, welche Methan als Kohlenstoffnahrung und Energiequelle gebrauchen, Zentrabl Bakteriol Parasitenk Infektionskr, 15, 513-517, 1906.

Song, C., Xu, X., Sun, X., Tian, H., Sun, L., Miao, Y., Wang, X., and Guo, Y.: Large methane emission upon spring thaw from natural wetlands in the northern permafrost region, Environ. Res. Lett., 7, 034009, doi:10.1088/1748-9326/7/3/034009, 2012.

Spahni, R., Wania, R., Neef, L., van Weele, M., Pison, I., Bousquet, P., Frankenberg, C., Foster, P. N., Joos, F., Prentice, I. C., and van Velthoven, P.: Constraining global methane emissions and uptake by ecosystems, Biogeosciences, 8, 1643-1665, doi:10.5194/bg8-1643-2011, 2011.

Ström, L., Mastepanov, M., and Christensen, T. R.: Species-specific effects of vascular plants on carbon turnover and methane emissions from wetlands, Biogeochemistry, 75, 65-82, 2005.

Summons, R. E., Franzmann, P. D., and Nichols, P. D.: Carbon isotopic fractionation associated with methylotrophic methanogenesis, Org. Geochem., 28, 465-475, 1998.

Tagesson, T., Mastepanov, M., Mölder, M., Tamstorf, M. P., Eklundh, L., Smith, B., Sigsgaard, C., Lund, M., Ekberg, A., and Falk, J. M.: Modelling of growing season methane fluxes in a high-Arctic wet tundra ecosystem 1997-2010 using in situ and high-resolution satellite data, Tellus B, 65, 19722, doi:10.3402/tellusb.v65i0.19722, 2013.

Tang, J. and Zhuang, Q.: Equifinality in parameterization of process based biogeochemistry models: A significant uncertainty source to the estimation of regional carbon dynamics, J. Geophys. Res.Biogeo., 113, G04010, doi:10.1029/2008JG000757, 2008.

Tang, J., Zhuang, Q., Shannon, R. D., and White, J. R.: Quantifying wetland methane emissions with process-based models of different complexities, Biogeosciences, 7, 3817-3837, doi:10.5194/bg-7-3817-2010, 2010.

Tang, J. Y. and Riley, W. J.: A total quasi-steady-state formulation of substrate uptake kinetics in complex networks and an example application to microbial litter decomposition, Biogeosciences, 10, 8329-8351, doi:10.5194/bg-10-8329-2013, 2013.

Tang, J. Y. and Riley, W. J.: Technical Note: Simple formulations and solutions of the dual-phase diffusive transport for biogeochemical modeling, Biogeosciences, 11, 3721-3728, doi:10.5194/bg-11-3721-2014, 2014.

Tian, H., Xu, X., Liu, M., Ren, W., Zhang, C., Chen, G., and Lu, C.: Spatial and temporal patterns of $\mathrm{CH}_{4}$ and $\mathrm{N}_{2} \mathrm{O}$ fluxes in terrestrial ecosystems of North America during 1979-2008: application of a global biogeochemistry model, Biogeosciences, 7, 2673-2694, doi:10.5194/bg-7-2673-2010, 2010.

Tokida, T., Mizoguchi, M., Miyazaki, T., Kagemoto, A., Nagata, O., and Hatano, R.: Episodic release of methane bubbles from peatland during spring thaw, Chemosphere, 70, 165-171, 2007.

Topp, E. and Pattey, E.: Soils as sources and sinks for atmospheric methane, Can. J. Soil Sci., 77, 167-177, 1997.
Tveit, A. T., Urich, T., Frenzel, P., and Svenning, M. M.: Metabolic and trophic interactions modulate methane production by Arctic peat microbiota in response to warming, P. Natl. Acad. Sci. USA, 112, E2507-E2516, 2015.

Valentine, D. L. and Reeburgh, W. S.: New perspectives on anaerobic methane oxidation, Environ. Microbiol., 2, 477-484, 2000.

van Bodegom, P. M., Leffelaar, P. A., Stams, A. J. M., and Wassmann, R.: Modeling methane emissions from rice fields: variability, uncertainty, and sensitivity analysis of processes involved, Nutr. Cycl. Agroecosys., 58, 231-248, 2000.

van Bodegom, P. M., Wassmann, R., and Metra-Corton, T. M.: A process-based model for methane emission predictions from flooded rice paddies, Global Biogeochem. Cy., 15, 247-263, 2001.

Van Oijen, M., Rougier, J., and Smith, R.: Bayesian calibration of process-based forest models: bridging the gap between models and data, Tree Physiol., 25, 915-927, 2005.

Volta, A.: Lettere dell'lllustrissimo Signor Volta Alessandro sull'aria inflammabile native dele paludi, in: Giuseppe Marelli, Milano, 1777.

Wagner, D., Lipski, A., Embacher, A., and Gattinger, A.: Methane fluxes in permafrost habitats of the Lena Delta: effects of microbial community structure and organic matter quality, Environ. Microbiol., 7, 1582-1592, 2005.

Wahlen, M.: The global methane cycle, Annu. Rev. Earth Pl. Sc., 21, 407-426, 1993.

Walter, B. P. and Heimann, M.: A process-based, climate-sensitive model to derive methane emissions from natural wetlands: Application to five wetland sites, sensitivity to model parameters, and climate, Global Biogeochem. Cy., 14, 745-765, 2000.

Walter, B. P., Heimann, M., Shannon, R. D., and White, J. R.: A process-based model to derive methane emissions from natural wetlands, Geophys. Res. Lett., 23, 3731-3734, 1996.

Wang, Z., Han, X., Wang, G. G., Song, Y., and Gulledge, J.: Aerobic methane emission from plants in the Inner Mongolia Steppe, Environ. Sci. Technol., 42, 62-68, 2007.

Wania, R.: Modelling northern peatland land surface processes, vegetation dynamics and methane emissions, Doktorarbeit, University of Bristol, Bristol, 1-140, 2007.

Wania, R., Ross, I., and Prentice, I. C.: Integrating peatlands and permafrost into a dynamic global vegetation model: 1 . Evaluation and sensitivity of physical land surface processes, Global Biogeochem. Cy., 23, GB3014, doi:10.1029/2008GB003412, 2009.

Wania, R., Ross, I., and Prentice, I. C.: Implementation and evaluation of a new methane model within a dynamic global vegetation model: LPJ-WHyMe v1.3.1, Geosci. Model Dev., 3, 565-584, doi:10.5194/gmd-3-565-2010, 2010.

Wania, R., Melton, J. R., Hodson, E. L., Poulter, B., Ringeval, B., Spahni, R., Bohn, T., Avis, C. A., Chen, G., Eliseev, A. V., Hopcroft, P. O., Riley, W. J., Subin, Z. M., Tian, H., van Bodegom, P. M., Kleinen, T., Yu, Z. C., Singarayer, J. S., Zürcher, S., Lettenmaier, D. P., Beerling, D. J., Denisov, S. N., Prigent, C., Papa, F., and Kaplan, J. O.: Present state of global wetland extent and wetland methane modelling: methodology of a model inter-comparison project (WETCHIMP), Geosci. Model Dev., 6, 617-641, doi:10.5194/gmd-6-617-2013, 2013.

Wassmann, R., Neue, H., Lantin, R., Makarim, K., Chareonsilp, N., Buendia, L., and Rennenberg, H.: Characterization of methane 
emissions from rice fields in Asia. II. Differences among irrigated, rainfed, and deepwater rice, Nutr. Cycl. Agroecosys., 58, 13-22, 2000.

Watanabe, K. and Ito, M.: In situ observation of the distribution and activity of microorganisms in frozen soil, Cold Reg. Sci. Technol., 54, 1-6, 2008.

Watts, J. D., Kimball, J. S., Parmentier, F. J. W., Sachs, T., Rinne, J., Zona, D., Oechel, W., Tagesson, T., Jackowicz-Korczynski, M., and Aurela, M.: A satellite data driven biophysical modeling approach for estimating northern peatland and tundra $\mathrm{CO}_{2}$ and $\mathrm{CH}_{4}$ fluxes, Biogeosciences, 11, 1961-1980, doi:10.5194/bg-111961-2014, 2014.

Weller, G., Chapin, F. S., Everett, K. R., Hobbie, J. E., Kane, D., Oechel, W. C., Ping, C. L., Reeburgh, W. S., Walker, D., and Walsh, J.: The arctic flux study: A regional view of trace gas release, J. Biogeogr., 22, 365-374, 1995.

Whiting, G. J. and Chanton, J. P.: Control of the diurnal pattern of methane emission from emergent aquatic macrophytes by gas transport mechanisms, Aquat. Bot., 54, 237-253, 1996.

$\mathrm{Xu}, \mathrm{S}$., Jaffe, P. R., and Mauzerall, D. L.: A process-based model for methane emission from flooded rice paddy systems, Ecol. Model., 205, 475-491, 2007.

$\mathrm{Xu}, \mathrm{X}$.: Modeling methane and nitrous oxide exchanges between the atmosphere and terrestrial ecosystems over North America in the context of multifactor global change, PhD Dissertation, School of Forestry and Wildlife Sciences, Auburn University, Auburn, 199 pp., 2010.

Xu, X., Schimel, J. P., Thornton, P. E., Song, X., Yuan, F., and Goswami, S.: Substrate and environmental controls on microbial assimilation of soil organic carbon: a framework for Earth system models, Ecol. Lett., 17, 547-555, 2014.

Xu, X., Elias, D. A., Graham, D. E., Phelps, T. J., Carrol, S. L., Wullschleger, S. D., and Thornton, P. E.: A microbial functional group based module for simulating methane production and consumption: application to an incubation permafrost soil, J. Geophys. Res.-Biogeo., 120, 1315-1333, 2015.

$\mathrm{Xu}, \mathrm{X}$. and Tian, H.: Methane exchange between marshland and the atmosphere over China during 1949-2008, Global Biogeochem. Cy., 26, GB2006, doi:10.1029/2010GB003946, 2012.

Xu, X. F., Tian, H. Q., Zhang, C., Liu, M. L., Ren, W., Chen, G. S., Lu, C. Q., and Bruhwiler, L.: Attribution of spatial and temporal variations in terrestrial methane flux over North America, Biogeosciences, 7, 3637-3655, doi:10.5194/bg-7-3637-2010, 2010.
Xu, X. F., Hahn, M., Kumar, J., Yuan, F. M., Tang, G. P., Thornton, P., Torn, M., and Wullschleger, S.: Upscaling plot-scale methane flux to an eddy covariance tower domain in Barrow, AK: integrating in-situ data with a microbial functional group-based model, AGU Annual Fall meeting, San Francisco, 2014.

Yokota, T., Yoshida, Y., Eguchi, N., Ota, Y., Tanaka, T., Watanabe, H., and Maksyutov, S.: Global concentrations of $\mathrm{CO}_{2}$ and $\mathrm{CH}_{4}$ retrieved from GOSAT: First preliminary results, Sola, 5, 160163, 2009.

Yvon-Durocher, G., Allen, A. P., Bastviken, D., Conrad, R., Gudasz, C., St-Pierre, A., Thanh-Duc, N., and Del Giorgio, P. A.: Methane fluxes show consistent temperature dependence across microbial to ecosystem scales, Nature, 507, 488-491, 2014.

Zhang, Y., Sachs, T., Li, C., and Boike, J.: Upscaling methane fluxes from closed chambers to eddy covariance based on a permafrost biogeochemistry integrated model, Glob. Change Biol., 18, 1428-1440, 2012.

Zhu, X., Zhuang, Q., Chen, M., Sirin, A., Melillo, J., Kicklighter, D., Sokolov, A., and Song, L.: Rising methane emissions in response to climate change in Northern Eurasia during the 21 st century, Environ. Res. Lett., 6, 045211, doi:10.1088/17489326/6/4/045211, 2011.

Zhu, Q., Riley, W. J., Tang, J., and Koven, C. D.: Multiple soil nutrient competition between plants, microbes, and mineral surfaces: model development, parameterization, and example applications in several tropical forests, Biogeosciences, 13, 341-363, doi:10.5194/bg-13-341-2016, 2016.

Zhuang, Q., Melillo, J. M., Kicklighter, D. W., Prinn, R. G., McGuire, A. D., Steudler, P. A., Felzer, B. S., and $\mathrm{Hu}$, S.: Methane fluxes between terrestrial ecosystems and the atmosphere at northern high latitudes during the past century: A retrospective analysis with a process-based biogeochemistry model, Global Biogeochem. Cy., 18, GB3010, doi:10.1029/2004GB002239, 2004.

Zona, D., Gioli, B., Commane, R., Lindaas, J., Wofsy, S. C., Miller, C. E., Dinardo, S. J., Dengei, S., Sweeney, C., Karion, A., Chang, R. Y.-W., Henderson, J. M., Murphy, P. C., Goodrich, J. P., Moreaux, V., Liljedahi, A., Watts, J. D., Kimball, J. S., Lipson, D. A., and Oechel, W. C.: Cold season emissions dominate the Arctic tundra methane budget, P. Natl. Acad. Sci. USA, 113, 40-45, 2016. 